\title{
Rituais funerários e deposição cerâmica nos sítios AM 41 e La Pointe de Balaté: repensando o período cerâmico tardio na planície costeira oeste da Guiana Francesa Mortuary rites and ceramic depositions at AM 41 and La Pointe de Balaté: rethinking the Late Ceramic Age of the Western Coastal Plain of French Guiana
}

\author{
Martijn van den Bel \\ Institut national de recherches archéologiques préventives. Caiena, Guiana Francesa
}

Resumo: Por mais de 20 anos se pensou que o período cerâmico tardio (900-1500 A.D.) das planícies costeiras do oeste da Guiana Francesa e do leste do Suriname teria sido dominado pelo complexo Barbakoeba, conforme definido pelo arqueólogo holandês Arie Boomert (1993). Recentemente, várias escavações permitiram enfatizar numerosas diferenças regionais baseadas na análise cerâmica e deposições funerárias. Este artigo tenta ir além da caracterização geral da cerâmica do complexo Barbakoeba, a fim de discutir a diversidade regional deste complexo amplamente distribuído.

Palavras-chave: Guiana Francesa. Suriname. Período cerâmico tardio. Barbakoeba. Práticas funerárias.

Abstract: For over 20 years the Late Ceramic Age (AD 900-1500) of the Western Coastal Plain of French Guiana and Eastern Suriname has been considered as dominated by the Barbakoeba ceramic complex as defined by the Dutch archaeologist Arie Boomert (1993). Recently, however, various excavations permit to emphasize numerous regional differences based on ceramic analysis and funerary depositions. This paper tries to go beyond general ceramic characteristics of the Barbakoeba ceramic complex in order to acknowledge regional diversity within this widely distributed complex.

Keywords: French Guiana. Suriname. Late Ceramic Age. Barbakoeba. Funerary practices.

\footnotetext{
VAN DEN BEL, Martijn. Rituais funerários e deposição cerâmica nos sítios AM 41 e La Pointe de Balaté: repensando o período cerâmico tardio na planície costeira oeste da Guiana Francesa. Boletim do Museu Paraense Emílio Goeldi. Ciências Humanas, v. 10, n. 1, p. 11-45, jan.-abr. 2015. DOI: http://dx.doi.org/10.1590/1981-81222015000100002.

Autor para correspondência: Martijn van den Bel. Institut national de recherches archéologiques préventives (INRAP). 842, Chemin Saint Antoine - 97300. Caiena, Guiana Francesa (martijn.van-den-bel@inrap.fr).

Recebido em 05/09/2014

Aprovado em 09/12/2014

Responsabilidade editorial: Denise Cavalcante Gomes
}

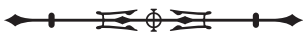




\section{INTRODUÇÃO}

O complexo cerâmico Barbakoeba foi definido por Arie Boomert, em 1993, no leste do Suriname e oeste da Guiana Francesa, estando situado, de modo amplo, entre o médio rio Commewijne e o baixo rio Mana. Este complexo, vinculado às séries cerâmicas Arauquinoides, foi associado aos campos elevados na última área e acredita-se que abranja o período entre 650 e 1200 A.D. Um ano depois, esta hipótese foi adotada por Stéphen Rostain (1994, p. 439-441) em sua tese de doutorado, apontando que "nenhum sítio Barbakoeba foi registrado ao leste do Kourou, mas a ausência de dados arqueológicos no litoral entre os rios Mana e Karouabo impediu a delimitação da extensão exata do complexo Barbakoeba na Guiana Francesa" (Rostain, 1994, p. 439).

Apesar da falta de dados para a região oeste do rio Kourou e da possível extensão do complexo cerâmico Thémire em torno do rio Mana, Rostain considerou o rio Kourou como uma fronteira regional entre o complexo Barbakoeba da planície costeira e o complexo Thémire da ilha de Caiena (Rostain, 1994, p. 443). De fato, acredita-se que "os sítios entre os rios Sinnamary e Kourou possuem dois componentes: cerâmica Barbakoeba e Thémire" (Rostain e Versteeg, 2004, p. 237). Os autores também sugeriram outra distribuição temporal para Barbakoeba, entre 1000 e 1400 A.D., baseados em Versteeg e Bubberman (1992), e depois propuseram que a cultura Thémire lentamente substituiu a Barbakoeba.

Boomert (1993, p. 205) já havia sugerido que "a tradição cultural Barbakoeba desapareceu devido à assimilação e finalmente incorporação à sociedade Koriabo", que gradualmente se expandiu para oeste, a partir da porção leste das Guianas. Boomert continuou afirmando que a conjectura proposta por Rostain e Versteeg seria pouco provável, pois não havia evidência disponível de que os campos elevados do norte tenham sido cultivados na época da ocupação Barbakoeba. Conforme demonstrado neste artigo, a inserção e fim da cultura Barkaboeka está em debate, o que se deve principalmente à falta de datações radiocarbônicas, mas também à falta de sítios na área intermediária anteriormente mencionada. De modo subsequente, a cronologia cultural da planície costeira entre os rios Suriname e Caiena permanece incerta, o que é problemático, devido à presença de sítios multicomponenciais, fator que aparentemente se complexifica nas margens arenosas, pois a leitura estratigráfica adequada neste ambiente torna-se prejudicada (Thooris, 1994, p. 12).

Escavações recentes realizadas nessa área, no sítio Iracoubo, e em terraços no baixo Maroni, nos sítios Saint-Louis e Balaté, testemunharam a evidência que permite repensar a cronologia cultural do suposto território Barbakoeba (Figura 1). Os resultados de vários estudos cerâmicos entre a ilha de Caiena e o rio Maroni, assim como numerosas datações radiocarbônicas, propiciaram novo material para fixar o complexo Barbakoeba nas planícies a oeste da Guiana Francesa depois de 900 A.D., mas também permite hipoteticamente pensar a inserção Koriabo depois de 1400 A.D., não só incorporando o complexo cerâmico Barbakoeba, mas também, substituindo o Thémire.

Inicialmente, será fornecida uma síntese das definições originais e subsequentes dos complexos cerâmicos existentes (Barbakoeba, Thémire, Koriabo). Em segundo lugar, serão apresentados os resultados dos inventários cerâmicos de escavações recentes, os quais serão comparados com as descrições originais, bem como, às análises tecnológicas conduzidas por Claude Coutet (2009, 2014a) para os três sítios Barbakoeba'.

\section{ESTADO ATUAL DO CONHECIMENTO}

\section{COMPLEXO BARBAKOEBA}

Arie Boomert (1977, p. 512) identificou seis sítios arqueológicos, localizados na costa leste do Suriname, a fim de separar esta cerâmica do material relacionado à

A análise modal (Rouse, 1939, 1960) tem sido usada no estudo desses conjuntos cerâmicos, enquanto a nomenclatura segue Hélène Balfet et al. (1989) e Prudence Rice (1987).

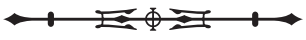




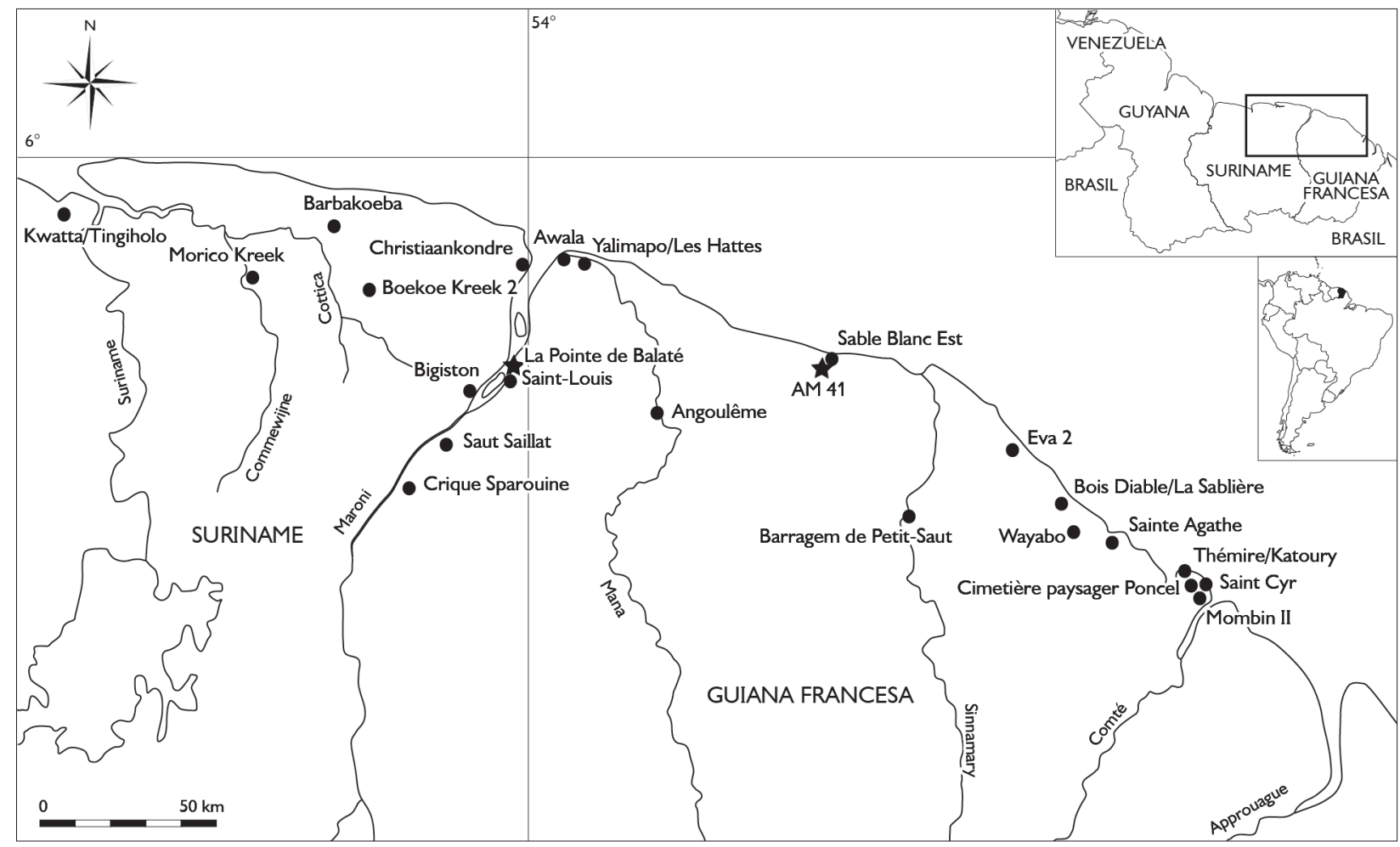

Figura 1. Mapa da costa da Guiana Francesa com os sítios mencionados no texto.

cultura Kwatta, e denominou estes sítios de "Barbakoeba stijlgroep". Cerca de 15 anos depois, ele definiu o complexo cerâmico Barbakoeba e associou-o à tradição Arauquinoide (Boomert, 1993, p. 205). O autor propôs a cronologia deste complexo entre 650 e 1200 A.D., embora existisse apenas uma datação radiocarbônica, a qual foi obtida por Aad Versteeg no sítio Boekoe Kreek 2. Esta amostra de carvão foi coletada em uma sondagem entre 15 e $20 \mathrm{~cm}$ de profundidade, e forneceu uma data de $975 \pm 50 \mathrm{AP}$ (GrN-7936), calibrada por volta de 1050 A.D. Uma outra amostra de carvão foi obtida do sítio Koriabo de Morico Kreek, que resultou na data de $455 \pm 65$ AP (GrN-2321), considerada muito antiga por Boomert, e então descartada.

A análise cerâmica realizada por Boomert (1993) foi baseada em cerca de 500 fragmentos coletados na superfície de sete diferentes sítios e de uma única sondagem. Os outros sítios estão localizados entre Wane Creek e na confluência dos rios Cottica e Commewijne. Os elementos diagnósticos são caco moído como tempero e jarros com gargalo, que representam a forma típica deste complexo (Boomert, 1993, p. 206). Bordas corrugadas representam outro elemento decorativo diagnóstico no Suriname (Boomert, 1993, p. 202), mas também na costa da Guiana Francesa (Rostain et al., 2008, p. 38).

Por outro lado, o Projeto Earthmovers propiciou sete datações radiocarbônicas para o sítio Barbakoeba de Sable Blanc Est, estabelecendo a ocupação para as áreas escavadas entre 1000 AP e 800 AP, ou seja, durante a primeira metade do período cerâmico tardio ou Late Ceramic Age (LCA) (McKey et al., 2010, tabela S1)2.

2 Deve-se destacar que o Projeto Earthmovers não forneceu qualquer inventário do material cerâmico escavado, tanto de Sable Blanc Est quanto de Bois Diable/La Sablière. Claude Coutet (2009) fez uma seleção do material cerâmico que havia sido coletado em campo.

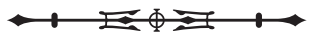


Apesar de estas datas e daquelas já existentes, a cronologia de Barbakoeba, assim como de outros sítios Arauquinoides - tais como os complexos tardios Hertenrits, Kwatta e Thémire -, situa-se entre 1000 e 1400 A.D. (Versteeg e Bubberman, 1992; Rostain, 2008, p. 281)

\section{COMPLEXO THÉMIRE}

Os sítios deste complexo também são encontrados frequentemente nas margens arenosas das planícies holocênicas da Guiana Francesa central, situados entre o rio Kourou e a ilha de Caiena (Rostain, 1994, 2008, 2013). O sítio tipo Thémire está localizado em uma margem pleistocênica na parte noroeste da ilha de Caiena, em frente à baía Montabo (Rostain, 1989, 1994). Todo material arqueológico deste complexo foi encontrado durante caminhamentos realizados para fins de prospecção, por meio de poucas sondagens e de uma escavação sistemática, que foi sintetizada por Rostain em sua tese de doutorado, sobre o complexo cerâmico Thémire (Rostain, 1994).

Apesar dos estudos cerâmicos já existentes realizados na ilha de Caiena por Alain Cornette (1990), Rostain introduziu três tipos cerâmicos para Caiena: 'Caiena pintado' (Cayenne peint), 'Mahury inciso' (Mahury incisé) e 'Melchior com caraipé' (Melchior kwep), assim como outra classe chamada 'Montabo vermelho' (Montabo rouge). Sua tipologia está baseada em 7.874 fragmentos, encontrados em dez diferentes sítios, dos quais o tipo 'Caiena pintado' representa cerca de $70 \%$ de todo o conjunto. Todos estes tipos cerâmicos foram atribuídos às séries Arauquinoides, enquanto 'Caiena pintado' é atribuído à Tradição Polícroma, formando o complexo Thémire(Rostain, 1994, p. 221 ep. 408)4.

Esta cronologia-tipo foi baseada em apenas duas datações radiocarbônicas aceitas, realizadas com amostras de conchas: uma proveniente da escavação em Bois Diable em Kourou, de $510 \pm 40$ AP (OBDY-794) e a outra do sítio de Sainte-Agathe (Macouria), de $380 \pm 35$ AP (OBDY-796), sugerindo uma datação combinada entre 1400 e 1670 A.D. (Rostain, 1994, p. 224). Entretanto, estes resultados foram considerados muito recentes para uma afiliação direta Arauquinoide, e a cultura Thémire foi então interpretada como "uma manifestação da tradição Arauquinoide tanto geograficamente quanto cronologicamente" (Rostain, 2008, p. 292; 2013, p. 122)

Apesar destes resultados tardios, pareceu provável para Rostain e Versteeg (2003) que a cultura Thémire tivesse uma afiliação cultural com os sítios costeiros do Suriname do período cerâmico tardio (LCA), tais como Hertenrits, Kwatta e Barbakoeba. Desse modo, a hipótese destes autores sugere a ocupação para o complexo Thémire entre 900 e 1650 A.D., incorporando o complexo Thémire no quadro cultural existente para o oeste das Guianas (Rostain, 1994, 2008, 2013; Rostain e Versteeg, 2004). Do mesmo modo que para os complexos cerâmicos Barbakoeba e Hertenrits, os sítios do complexo Thémire são frequentemente rodeados por campos elevados, embora nenhum deles tenha sido encontrado na ilha de Caiena.

\section{COMPLEXO KORIABO}

As cerâmicas decoradas deste complexo são fáceis de reconhecer e têm sido interpretadas como uma troca entre os grupos pré-colombianos do período cerâmico tardio (Boomert, 1993), uma vez que elas têm sido identificadas em todo o escudo das Guianas (Evans e Meggers, 1960; Groene, 1976; Boomert, 1977, 1978, 1986, 1993, 2004; Hilbert, 1982; Versteeg, 1985, 2003; Rostain, 1994, 2008, 2009; Hildebrand, 2008; van den Bel, 2010; Cabral, 2011; Mestre e Hildebrand, 2011). De acordo com Rostain (2009, p. 47), o complexo Koriabo é um produto único das Guianas. $\bigcirc$

3 Datações radiocarbônicas relativas à ocupação tardia do sítio Hertenrits são inexistentes. A ocupação tardia de Hertenrits foi estabelecida indiretamente por meio do material cerâmico datado do sítio monticular de Prins Bernhard Polder.

4 Ele sugeriu que a influência policrômica Aristé (tardia) era unilateral, uma vez que os elementos diagnósticos Thémire estavam ausentes nos sítios Aristé (Rostain, 2008, p. 293).

5 Ironicamente, escavações recentes em Sainte-Agathe mostraram que o único resultado obtido por Yves Wack (1990) foi de fato correspondente ao período proto-contato (Samuelian, 2009). 
complexo cerâmico Koriabo foi definido em 1950 por Clifford Evans e Betty Meggers, que escavaram vários sítios no distrito noroeste da antiga Guiana britânica, sendo um deles chamado Ponto Koriabo (Evans e Meggers, 1960, p. 124-154)6.

O registro cerâmico da fase Koriabo está baseado na coleta de material em quatro sítios habitacionais, localizados nas barrancas dos rios Barima e Waini. O casal americano conduziu prospecções de sítios e realizou várias sondagens (13 $\mathrm{m}^{2}$ no total), nas quais 4.378 fragmentos foram obtidos, permitindo a eles estabelecer as primeiras características deste complexo. $O$ material escavado foi classificado em cinco tipos: 'Barima simples' (Barima plain), 'Koriabo simples' (Koriabo plain) e 'Warapoco simples' (Warapoco plain), bem como dois decorados, 'Koriabo inciso' (Koriabo incised) e 'Koriabo escovado' (Koriabo scraped). A presença ou a ausência de decoração, bem como a cor e a natureza de inclusões visíveis na pasta foram usadas para distinguir os seguintes tipos: com caraipé ou kwepi (Barima simples), areia grossa (Koriabo simples, inciso, escovado), ou areia grossa misturada com quartzo transparente (Warapoco simples). Como "fragmentos obtidos por meio de troca" foram encontrados apenas na fase Mabaruma mais tardia, eles propuseram uma idade relativa ao período cerâmico tardio entre 1200 e 1600 A.D. (Evans e Meggers, 1960, p. 147-148).

Além disso, a cerâmica Koriabo encontrada no Suriname também apresenta pintura policrômica elaborada - preto e vermelho sobre engobo branco nos exemplares utilizados em contexto funerário, tendo sido chamada de Koriabo Pintada por Boomert (1986, p. 27-36). Desse modo, o autor associou a cerâmica Koriabo à tradição Polícroma da Amazônia (Boomert, 1986, p. 27; 2004, p. 261) 7.

Em 1986, Boomert apresentou uma importante hipótese, na qual a cerâmica Koriabo do Suriname é analisada e comparada com sua manifestação antilhana mais tardia, o chamado complexo Cayo. Sua análise morfológica, em combinação com as frequências dos modos de decoração, apontou treze formas. Ele identificou várias formas comuns (Formas 1, 3, 4, 8, 9 e 10), duas especiais (Formas 2 e 12) e duas diagnósticas (Formas 5 e 11). Elas representam as formas típicas Koriabo, com as chamadas tigelas com bordas e incisões profundas formando lóbulos e os jarros com gargalo, respectivamente (Evans e Meggers ,1960, p. 133, figura 53).

A maioria dos sítios Koriabo pode ser encontrada nos rios maiores, em seus afluentes e, particularmente, na sua junção, mas também pode ser identificada nas margens arenosas das planícies costeiras (Boomert, 2004, p. 252). $\mathrm{Na}$ Guiana Francesa, a cerâmica Koriabo também tem sido associada aos sítios com diques, tais como Angoulême, no baixo rio Mana e no rio Pointe Morne, no baixo rio Oyapock (Kayamaré, 1997; Hildebrand, 2002; Mestre, 2006; Mestre e Hildebrand, 2011; Gassies e Dauphin, 2013). Além disso, também tem sido evidenciado que estes sítios possuem múltiplas ocupações.

\section{SÉRIES CERÂMICAS DE BALATÉ E IRACOUBO}

\section{O SÍTIO LA POINTE DE BALATÉ}

O sítio La Pointe de Balaté (Balaté), do período cerâmico tardio, está localizado na margem direita do rio Maroni, na boca do igarapé Balaté, e foi escavado por membros do Institut national de recherches archéologiques préventives (INRAP) em 2009 (Briand, 2015). Ele possui uma ocupação contemporânea ao sítio Chemin Saint-Louis (Saint-Louis), o qual foi escavado pelo autor no mesmo ano (van den Bel, 2012). O material cerâmico de Balaté foi coletado

6 De acordo com Cornelius Osgood (1946, p. 32), o sítio tipo Koriabo foi provavelmente descoberto em 1905 pelo antropólogo Elias Torro, quando explorou a Guiana britânica e a fronteira venezuelana.

7 Os primeiros fragmentos Koriabo na Guiana Francesa foram coletados durante a metade dos anos 1970, na margem direita do médio rio Marconi, na aldeia Kormontibo (Groene, 1976). O material Koriabo encontrado na Guiana Francesa foi redefinido por Stéphen Rostain graças à sua tese de doutorado, criando um tipo totalmente novo chamado "Chaton fantastique" (Rostain, 1994, p. 199-212). A maioria do material arqueológico estudado por ele consiste em vasilhas completas e quase completas, das quais a maior parte foi encontrada nas corredeiras do rio Approuage (Migeon et al., 2010).

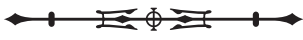


durante a décapage mecânica de 11 setores ou zonas, e a partir de 160 feições (Tabela 1). Apenas 1\% do material coletado é decorado, sendo distribuído entre a décapage e as feições, fazendo com que a coleta das feições represente dois terços da coleta total. Os elementos constituintes (EC) incluem seis vasilhas completas e são representados por 82 bordas, 63 bases e sete assadores ( $N=147$ ).

\section{AS BORDAS}

A coleção de bordas - excluindo os assadores - consiste em 82 indivíduos. A variedade de bordas permitiu criar uma distribuição morfológica de oito séries modais (SM I-VIII), das quais SM I e SM III são as séries mais populares, representando dois terços (63\%) da contagem de bordas (Tabela 2). Quando conduzimos o estudo, encontramos um tratamento labial como importante marcador, distinguindo perfil retilíneo, côncavo e convexo tanto para vasilhas abertas como restritas, o que permitiu criar seis diferentes subséries. Esta divisão foi novamente enriquecida pela medida de diâmetro e espessura da parede, bem como pelo registro do antiplástico e dos modos de queima.

Os elementos únicos (SM VIII) foram excluídos depois do estudo. SM VII representa os gargalos ou garrafas nos quais o diâmetro é menor do que $14 \mathrm{~cm}$, tendo sido considerado um elemento conclusivo para a repartição morfológica (Tabela 2). Concentrações cerâmicas notáveis (Feições 115 e 123) foram de particular interesse, uma vez que propiciaram numerosos elementos constituintes para a repartição morfológica. $\bigcirc$ estudo da pasta de todos os fragmentos foi realizado com o auxílio de uma pequena binocular, com aumento de 8x, após uma ou várias quebras do fragmento para se obter um corte recente.

Quatro elementos principais foram observados como antiplástico, entre eles o mineral, o vegetal, a mistura destes e o caco moído, os quais são todos igualmente populares, mas o tempero vegetal - no caso as cinzas de cascas de árvore $(\mathrm{N}=22)$ - é o mais popular deles em cerca de 30\% da amostra (Tabela 3). Em alguns casos, o caco moído e a areia também foram observados em
Tabela 1. Contagem geral da cerâmica do sítio La Pointe de Balaté.

\begin{tabular}{c|c|c|c|c|c}
\hline & Simples & Decorado & $\mathrm{N}$ & Peso $(\mathrm{g})$ & $\mathrm{EC}$ \\
\hline Décapage & 2.270 & 37 & 2.304 & 37.362 & 57 \\
\hline Estruturas & 4.327 & 36 & 4.363 & 63.811 & 90 \\
\hline Total & 6.597 & 73 & 6.667 & 101.173 & 147 \\
\hline
\end{tabular}

Tabela 2. Séries modais (SM) de bordas (SM I-VIII) do sítio La Pointe de Balaté. Legendas: $A=$ aberta; $R=$ restrita (fechada); $X=$ não determinada.

\begin{tabular}{c|c|c|c|c}
\hline SM & Forma & Perfil & Lábio & N \\
\hline Ia & A & Retilíneo & & 11 \\
\hline Ib & A & Retilíneo & Extrovertido & 9 \\
\hline Ic & A & Retilíneo & Extrovertido & 7 \\
\hline II & A & Retilíneo a côncavo & Reforçado & 3 \\
\hline IIla & A & Convexo & & 10 \\
\hline IIIb & A & Convexo & Extrovertido & 10 \\
\hline IIIc & A & Convexo & Reforçado & 6 \\
\hline IV & A & Retilíneo a côncavo & Biselado & 7 \\
\hline Va & $R$ & Retilíneo & & 4 \\
\hline Vb & $R$ & Convexo & Plano & 5 \\
\hline VI & $R$ & Altamente convexo & & 5 \\
\hline VII & $R$ & Miscelânea (garrafas) & & 3 \\
\hline VIII & $\times$ & Único & & 2 \\
\hline & & & & Total: 82 \\
\hline
\end{tabular}

Tabela 3. Distribuição dos modos de tempero do sítio La Pointe de Balaté.

\begin{tabular}{|c|c|c|c|c|}
\hline & & Descrição & Modo & $\mathrm{N}$ \\
\hline \multirow{3}{*}{$\begin{array}{c}\text { Mineral } \\
(21 \%)\end{array}$} & \multirow{3}{*}{1} & Areia & 11 & 18 \\
\hline & & Areia + mica & 12 & 11 \\
\hline & & Areia + mica + minerais & 13 & 2 \\
\hline \multirow{2}{*}{$\begin{array}{l}\text { Vegetal } \\
(30 \%)\end{array}$} & \multirow{2}{*}{2} & Carvão & 21 & 2 \\
\hline & & Cinzas & 22 & 42 \\
\hline \multirow{2}{*}{$\begin{array}{c}\text { Mistura } \\
(25 \%)\end{array}$} & \multirow{2}{*}{3} & Carvão + minerais & 31 & 10 \\
\hline & & Cinzas + minerais & 32 & 27 \\
\hline $\begin{array}{c}\text { Caco moído } \\
(24 \%)\end{array}$ & 4 & Caco moído & 41 & 35 \\
\hline & & & & Total: \\
\hline
\end{tabular}

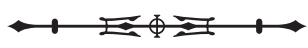


quantidades muito baixas, especialmente nos fragmentos em que predominam os temperos mineral e vegetal; nesses casos, os fragmentos têm sido atribuídos ao modo dominante de tempero, e não aos elementos misturados. Conchas moídas ou ossos queimados, assim como feldspato, foram observados. A mica representa um elemento particular e está claramente relacionada ao tempero mineral - não sendo observada em associação ao antiplástico vegetal, nas misturas ou ao caco moído - e associada a uma técnica de queima oxidada. Esta última técnica é representada em, aproximadamente, 20\% dos elementos. A queima reduzida é a mais popular (71\%), a qual está correlacionada aos temperos vegetal, misturas de antiplásticos e caco moído.

\section{SM I}

Essa série modal que consiste em 27 elementos (33\%) é a mais popular na área escavada. Junto com SM III, estas séries referem-se à abundância de vasilhas abertas nesse sítio (77\%). $\bigcirc$ tratamento labial foi visto como um meio de classificar os diferentes perfis, retilíneos, não modificados, extrovertidos e reforçados, entre os quais o lábio extrovertido (everted lip) representa um elemento característico (60\%). A espessura média da parede é de $8 \mathrm{~mm}$, e varia entre 5 e $12 \mathrm{~mm}$, enquanto os diâmetros variam entre 20 e 60 cm. Quando consideramos o diâmetro médio $(36 \mathrm{~cm})$ do número mais frequente $(\mathrm{N}=1,7)$ como elemento determinante, a frequência mais alta é observada entre 28 a $36 \mathrm{~cm}$, mas também entre 42 a $50 \mathrm{~cm}$, a última sugerindo formas mais amplas (Figura 2) . $^{8}$

As frequências refletem a distribuição do tratamento labial, pois, quando o diâmetro é calculado do mesmo modo por subséries, os diâmetros mais amplos $(50 \mathrm{~cm})$ são significativos para SM Ic, e os menores representam SM la e SM Ib, ou 32 e 28 cm, respectivamente. Esta série é caracterizada pelo tempero vegetal, elementos misturados e caco moído, nos quais o mineral está presente apenas em dois indivíduos. A queima reduzida é quase exclusiva. A decoração está ausente. Apenas um vaso

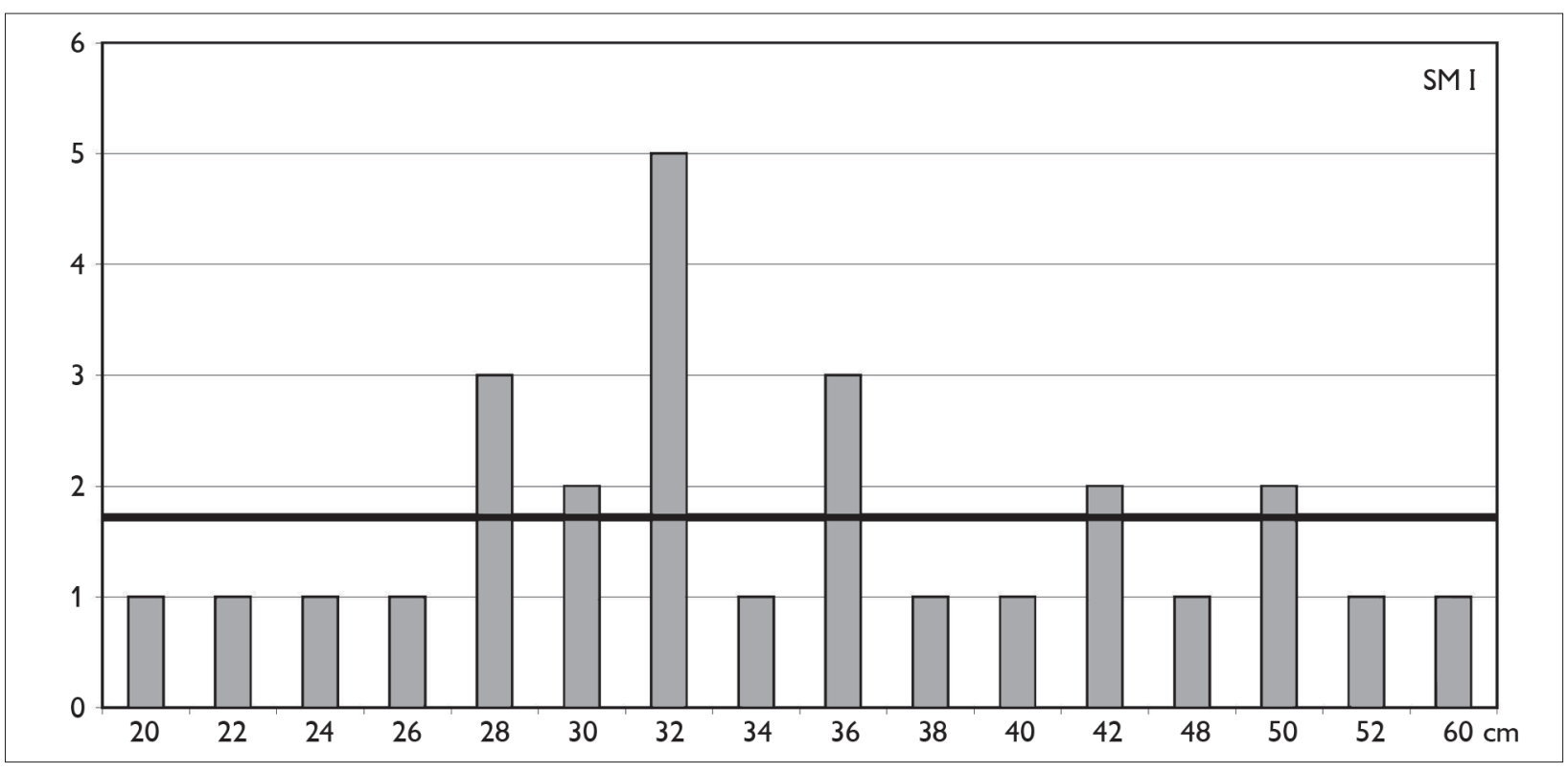

Figura 2. Frequência dos diâmetros de SM I do sítio La Pointe de Balaté.

\footnotetext{
8 Note que diâmetros acima de $30 \mathrm{~cm}$ foram medidos a cada $2 \mathrm{~cm}$.
}

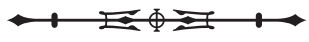


completo foi recuperado, uma vasilha aberta elipsoide (em forma de barco) (EC 21, Figura 4A).

\section{SM III}

Tão popular quanto SM I é SM III, com 26 indivíduos (30\%). Novamente, o tratamento labial permitiu distinguir três subséries pelos perfis convexos, não modificados (lábios principalmente arredondados ou planos), extrovertidos e expandidos, dos quais o extrovertido é o mais popular (60\%). A espessura média da parede é de $7 \mathrm{~mm}$, e varia entre 4 e $10 \mathrm{~mm}$, sendo que o diâmetro varia entre $16 \mathrm{e}$ $40 \mathrm{~cm}$. A única vasilha miniatura (EC 55) foi excluída. Existe um alto número de vasilhas com três diferentes modos de diâmetros, entre 24, 28 e $38 \mathrm{~cm}$, dos quais o primeiro é o mais popular (Figura 3).

A decoração é quase ausente, exceto em uma pequena tigela com pintura vermelha em ambas as faces (EC 92, Figura 4G). Existe uma tigela completa, com uma borda com entalhes e pequenos apliques esféricos (EC 7, Figura 5A). Aqui apontamos EC 46 e 47 (SM IIla), que compartilham uma feição particular, com um reforço espatulado ao redor da parte superior da vasilha, aplicado a poucos centímetros abaixo do lábio, sugerindo a presença de uma inclinação na direção oposta (carena) (EC 47, Figura 4F). Ambos os fragmentos de borda são temperados com areia e possuem um diâmetro de $38 \mathrm{~cm}$, podendo ser parte de vasilhas complexas do tipo 'com orelhas' ou ter bordas convexas com carena (eared vessels). Finalmente, a queima e o tempero são dominados por técnicas redutivas e material vegetal (caraipé), como em SM I.

\section{SM IV E SM V}

As séries seguintes são claramente minoritárias, das quais SM IV e SM V são as mais populares. Embora estas séries não sejam tão populares, elas representam fortes marcadores do conjunto, notadamente com relação a formas específicas e aos modos de decoração. Ambas as séries têm formas características, bordas diretas ou côncavas, com gargalo em SM IV e restritas ou convexas em SM V. O tratamento labial permitiu definir uma subsérie para SM V, assim como SM IV é caracterizada por lábios biselados e fortemente angulares, dos quais um lábio biselado

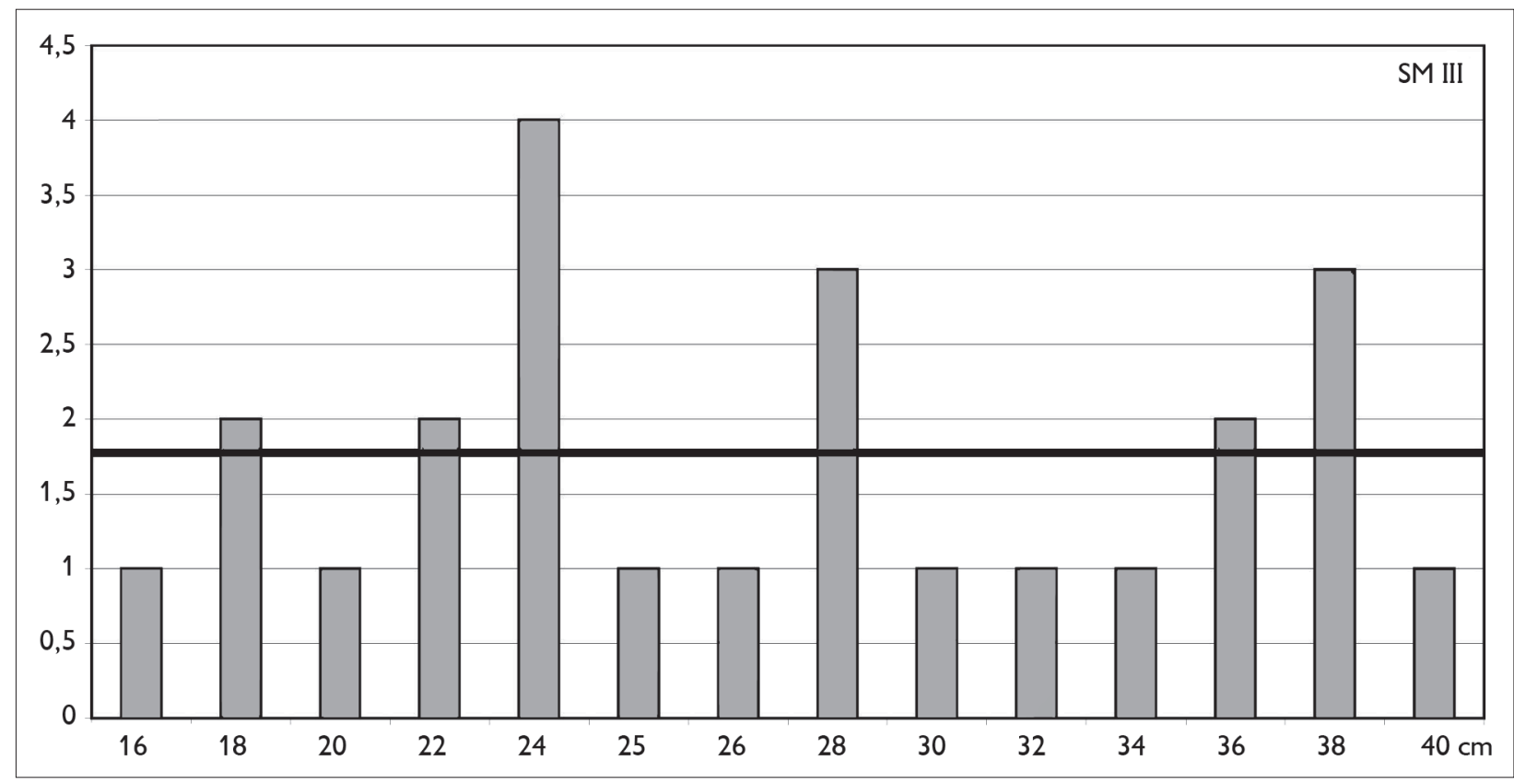

Figura 3. Frequência dos diâmetros de SM III do sítio La Pointe de Balaté. 
parece uma dupla ranhura escovada (EC 61) $)^{9}$. As subéries SM Vb possuem lábios apontados, sendo que três indivíduos mostram decoração de filetes aplicados com digitado no exterior. Um elemento também mostra uma alça decorativa colocada sobre o lábio da vasilha (EC 94, Figura 5K). De forma interessante, ambas as séries também parecem ter modos próprios de tempero: SM IV possui predominantemente tempero de areia, enquanto em SM $\vee$ o caco moído é mais ou menos predominante como tempero, sugerindo claramente dois diferentes tipos de artefatos.

\section{AS SÉRIES REMANESCENTES}

Estes são os modos menos populares, mas SM II e SM VII apresentam elementos morfológicos altamente característicos, entre eles bordas inclinadas externas e gargalos pequenos, respectivamente. Gargalos temperados com caco moído em SM VII possuem diâmetros menores do que $14 \mathrm{~cm}$ e provavelmente representam os gargalos de grandes vasos globulares ou jarros, quase sempre encontrados em contextos funerários acima da planície oeste da Guiana Francesa (Coutet, 2011, 2014b; Coutet et al., 2014). Um pequeno elemento possui um filete aplicado e digitado ao redor do pescoço (EC 91, Figura 5J).

As bordas inclinadas externas, temperadas com areia do modo SM II, representam tigelas rasas e abertas com diâmetros com cerca de $30 \mathrm{~cm}$, sendo caracterizadas por pintura branca no seu interior e com bordas serrilhadas regularmente formando grandes lóbulos. SM VI representa vasilhas restritas de vários tamanhos, das quais duas foram encontradas em contextos funerários com urnas tendo tempero de areia ou vegetal. Finalmente, SM VIII contém apenas dois elementos, que não se encaixam nas descrições acima mencionadas e não apresentam nenhuma semelhança morfológica entre elas.

\section{As bases}

O registro de bases é composto por 63 indivíduos ou $42 \%$ do total dos elementos constituintes, as quais foram divididas em quatro séries modais, subdivididas novamente de acordo com a maneira pela qual o primeiro rolete foi aplicado à base (Tabela 4). As bases planas são as mais populares (57\%), seguidas pelas côncavas (38\%). Bases em pedestal são raras. Apenas o EC 40 (Figura 5B) possui pintura branca aplicada ao seu interior; todos os outros fragmentos de bases não são decorados.

As séries modais de bases planas ( $N=36$ ) foram divididas de acordo com o perfil - convexa (SM 1a, 36\%), retilínea (SM 1b, 25\%), côncava (SM 1c, 14\%) ou em pedestal (SM 1d, 25\%) -, das quais o modo convexo é o mais popular. A espessura da base tem, em média, $8 \mathrm{~mm}$ e varia entre 4 e $15 \mathrm{~mm}$, enquanto os diâmetros variam entre 2 e $17 \mathrm{~cm}$, com uma média de 8,6 cm. Para as bordas, o tempero vegetal, os elementos misturados e o caco moído são comuns nessas séries. Bases temperadas com areia são raras. As bases com cavidade $(\mathrm{N}=24)$ possuem dois perfis principais, sendo o anular um pouco mais popular em relação ao convexo. A espessura varia entre 6 e $15 \mathrm{~mm}$, com uma média de $9 \mathrm{~mm}$, enquanto os diâmetros estão entre 4 e $14 \mathrm{~cm}$, com uma média de $9,4 \mathrm{~cm}$. Bases ovoides estão presentes nessas séries. $\bigcirc$ tempero vegetal é dominante e a decoração, ausente. As séries remanescentes são de menor interesse.

Tabela 4. Séries modais de bases (SM 1-4) do sítio La Pointe de Balaté. Legenda: $X=$ não determinada.

\begin{tabular}{c|c|c|c}
\hline SM & Forma & Perfil & N \\
\hline $1 a$ & Plana & Convexo & 13 \\
\hline $1 b$ & Plana & Retilíneo & 9 \\
\hline 1c & Plana & Côncavo & 5 \\
\hline $1 d$ & Plana & Apendicular & 9 \\
\hline $2 a$ & Côncava & Convexo & 10 \\
\hline $2 b$ & Côncava & Anelar & 12 \\
\hline 3 & Pedestal & Retilíneo & 1 \\
\hline 4 & Não determinada & $\times$ & 4 \\
\hline
\end{tabular}

\footnotetext{
9 elemento constituinte 61 não está figurado.
} 


\section{Os assadores}

A classe dos assadores é representada apenas por sete indivíduos ou 7\% do total dos elementos constituintes. Os assadores foram divididos de acordo com as morfologias da borda, entre as quais os lábios arredondados (SMA) são os mais populares. A espessura (entre 12 e $24 \mathrm{~mm}$ ) e os diâmetros (entre 30 e $50 \mathrm{~cm}$ ) revelam pequenos assadores. O tempero é predominantemente constituído por elementos misturados. Entretanto, a pequena quantidade e qualidade comprometida da amostra, composta por pequenos fragmentos, propicia pouca informação. De um lado, este fato sugere que existiam poucos assadores no sítio habitacional, que foi possivelmente usado por um longo período. Por outro lado, a amostra também sugere a presença de assadores mais importantes relacionados a atividades fora da área habitacional.

\section{Os modos de decoração}

O número total de fragmentos decorados ( $\mathrm{N}=73$ ou 1\%) é limitado, mas a contagem de EC mostra uma porcentagem mais elevada, de 7\% (Tabela 5). O repertório decorativo é restrito e composto por pintura (20\%), incisão (11\%), filetes aplicados e digitados (16\%), figuras aplicadas ou modeladas (37\%) e apêndices modelados (16\%). As representações, principalmente os apêndices biomorfos modelados, com olhos esféricos feitos por meio de um instrumento circular, consistem no tipo mais popular. De modo geral, a modelagem é abundante em Balaté (70\%), sendo que a pintura e as incisões são claramente modos gerais de decoração. A pintura branca é mais frequente do que a vermelha. Apenas dois exemplares apresentam pintura branca sobre vermelho.

Um elemento interessante consiste em um pequeno número de fragmentos da feição 115 temperados com areia, pintados de branco, com filetes modelados e aplicados, representando uma face humana com olhos no formato de
Tabela 5. Séries modais dos assadores (SM A-C) do sítio La Pointe de Balaté.

\begin{tabular}{c|c}
\hline Decoração & N \\
\hline Pintura vermelha & 4 \\
\hline Pintura branca & 8 \\
\hline Pintura branca sobre vermelho & 2 \\
\hline Incisões & 8 \\
\hline Filetes aplicados & 12 \\
\hline Figuração & 27 \\
\hline Apêndices & 12 \\
\hline & Total: 73 \\
\hline
\end{tabular}

grãos de café, orelhas e nariz, que podem ter pertencido à parte superior de uma vasilha antropomorfa ${ }^{10}$. Outra peça excepcional é o EC 12 (Figura 5E), que é um pote 'tórico' com cinco câmaras, cada uma apresentando um círculo exciso, no qual é modelada uma face humana, com olhos e nariz"1.

Outro tipo de decoração plástica modelada é representado pelas asas simples ou duplas, pequenas esferas e possivelmente cabeças e patas estilizadas em vasilhas zoomorfas. As incisões variam desde séries de ungulados no lábio $(N=2)$ até incisões entalhadas no lábio $(\mathrm{N}=2)$. Filetes aplicados com digitado formam tanto asas quanto guirlandas na parte superior da vasilha (EC 94, Figura 5) ou ao redor da parte inferior do pescoço ou do gargalo (EC 91, Figura 5J). Uma asa é adornada com filetes aplicados e digitados (EC 94, Figura 5K). Por fim, um exemplar distinto consiste em um detalhe aplicado e ondulado, encontrado na Zona 9 (Figura 5L).

\section{Síntese de Balaté}

O conjunto cerâmico Balaté declina nos modos SM I e SM III, os quais são formados por grandes vasilhas abertas, caracterizadas por bordas extrovertidas e lábios angulares, representando cerca de $40 \%$ do total da contagem de elementos constituintes (Figura 4).

\footnotetext{
10 Os pequenos elementos da F 115 não estão figurados.

11 Um pote tórico é [Forma C ]: "Corpo com perfil tórico; corpo da vasilha se separando do pescoço e da base, resultando num aspecto de um toro", assim definido por Jérôme Briand (apud Vacher et al., 1998, p. 183, tabela XXIII).
} 


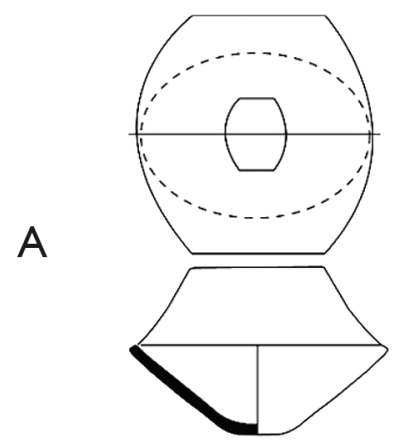

B

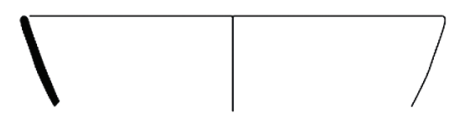

C

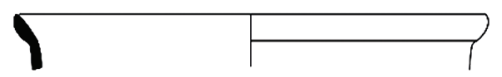

D

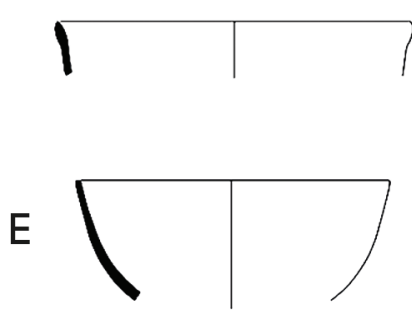

F

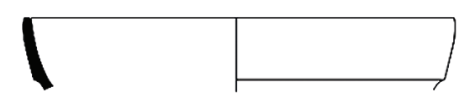

G
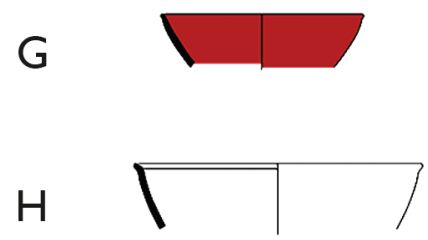
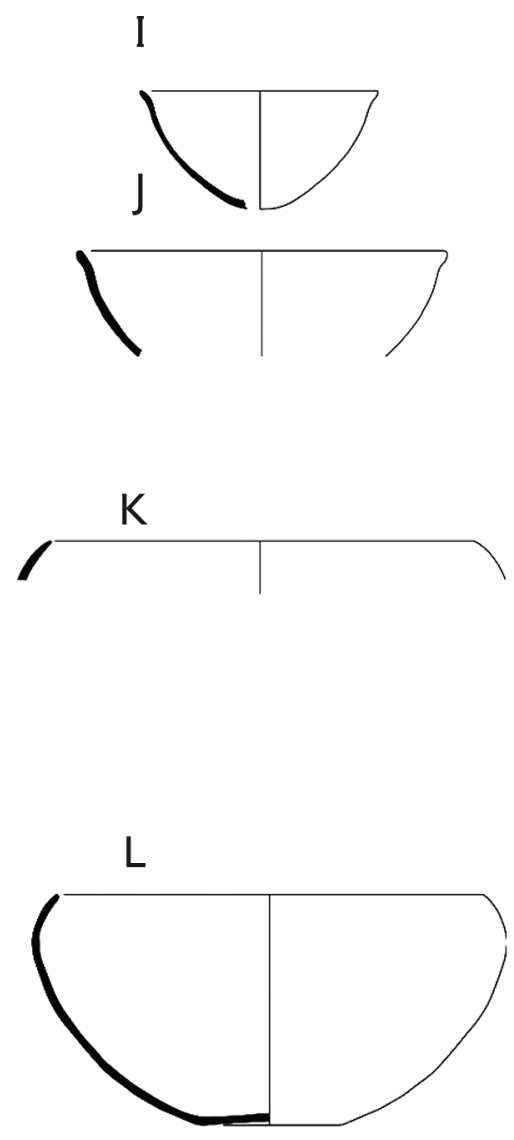

M

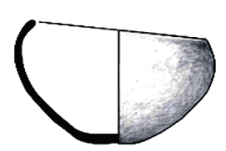

N

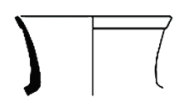

Figura 4. Reconstituições de várias formas modais do sítio La Pointe de Balaté: A) EC 21, SM Ia; B) EC 59, SM Ia; C) EC 37, SM Ic; D) EC 32, SM Ic; E) EC 17, SM IIla; F) EC 47, SM IIla; G) EC 92, SM IIla; H) EC 51, SM IIlb; I) EC 3, SM IIlb; J) EC 10, SM IIIb; K) EC 58, SM Vb; L) EC 11, SM VI; M) EC 1, SM VI; N) EC 22, SM VII. Desenhos de Christine Fouilloud (INRAP). 


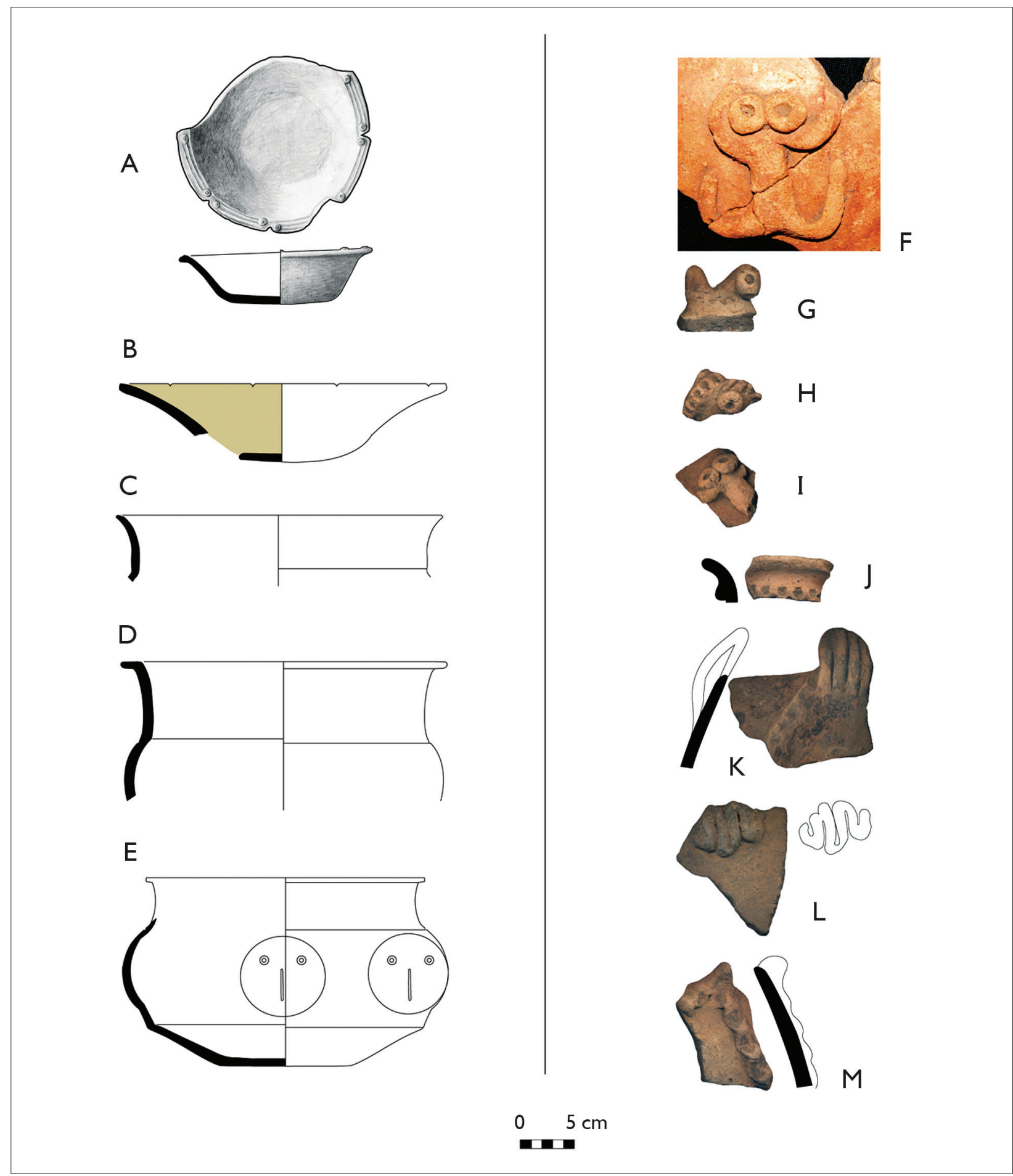

Figura 5. Vários elementos decorativos do sítio La Pointe de Balaté: A) EC 7, SM IV; B) EC 40, SM II; C) EC 49, SM IV; D) EC 60, SM IV; E) EC 12, SM IV; F) F 123; G) F 123; H) Zona 10; I) F 123; J) EC 91, SM VII; K) EC 94, SM Vb; L) Zona 9; M) EC 93, SM Vb. Fotos de Jérôme Briand (INRAP) e desenhos de Christinte Fouilloud (INRAP).

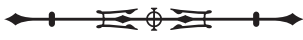


Estas vasilhas são predominantemente temperadas com vegetal, notadamente partículas de cinzas de casca de árvore de coloração acinzentada, conhecidas como kwepi ou caraipé. Entretanto, elementos misturados e caco moído também são traços importantes nessas séries, dominadas por uma técnica de queima redutora. Esta combinação confere aos fragmentos um toque suave, assim como no sítio vizinho Saint-Louis (van den Bel, 2012). Estas séries são pouco decoradas.

Embora menos frequente, as outras séries são facilmente reconhecíveis, notadamente por uma morfologia particular e pelo tempero, bem como pelos modos específicos de decoração. Aqui está incluída a pintura branca nas bordas inclinadas externas de SM II, os jarros com pescoço com lábios biselados de SM IV, os gargalos de SM VII, as vasilhas com bocas restritas e lábios apontados de SM $\vee$ e as bordas introvertidas de SM VI. Embora os elementos decorativos sejam geralmente raros, a modelagem, especialmente a representação nos apêndices biomorfos, assim como os filetes aplicados parecem marcar o repertório decorativo desse conjunto.

Das quinze datações radiocarbônicas, sete resultados claramente sugerem uma ocupação no período cerâmico tardio (LCA) para Balaté, situado entre 1000 e 1500 A.D. (Tabela 6). Seis amostras foram obtidas a partir de feições antropogênicas - enterramentos primários e secundários -, indicando uma datação mais segura. Um grupo de datas sugere uma idade histórica entre 1600 e 1850 A.D. $(\mathrm{N}=4)$, enquanto outro grupo $(\mathrm{N}=3)$ sugere a datação cerâmica mais antiga, situada na primeira metade do segundo milênio A.D. Os resultados de amostras tardias correspondem à Fase 2 do sítio Saint-Louis (van den Bel, 2012), entretanto nenhuma cerâmica desta fase foi identificada pelo presente autor em Balaté. Se, por um lado, as datações radiocarbônicas históricas podem ser corrigidas e sugerem ocupação histórica ameríndia de Balaté; por outro, os artefatos europeus são inexistentes para confirmar esta hipótese ${ }^{12}$. conjunto cerâmico de Balaté claramente mostra similaridades estilísticas com outros sítios cerâmicos tardios da costa, localizados na Guiana Francesa e no leste do Suriname. Na presente análise do sítio Saint-Louis Fase 3, a afiliação cultural de Balaté é integrada para criar um todo relativo ao período cerâmico tardio de Saint-Louis e Balaté. Além do tempero e da morfologia, aspectos decorativos são pouco partilhados entre os dois sítios, sugerindo uma possível função diferenciada desses espaços. Os filetes aplicados e digitados e os apêndices biomorfos modelados, registrados em Balaté, devem ser associados ao complexo Barbakoeba do leste da costa do Suriname, conforme definido por Boomert (1993). Apesar do fato de as bordas corrugadas estarem ausentes no período cerâmico tardio tanto em Saint-Louis quanto em Balaté, o último sítio claramente partilha traços morfológicos com Barbakoeba, tais como bases anelares, espessuras finas das paredes e, o mais importante, traços característicos, como lábios angulares (SM Ib e SM IIlb versus Boomert, 1993, p. 204, figuras 3.2 e 3.3; base anelar na última), gargalos com filetes aplicados e digitados (SM VII versus Boomert, 1993, p. 206, figuras 5.2-5.4) ou não decorados (SM VII versus Boomert, 1993, p. 206, figura 5.5), bordas com "orelhas" (Boomert, 1993, p. 208, figura 6.8 e p. 210, figura 7.2), mas também vasilhas restritas (SM VI versus Boomert, 1993, p. 208, figura 6.1).

Embora Balaté possua como tempero dominante o kwepi (caraipé), o caco moído - o tempero dominante de Barbakoeba - também aparece e, em menor quantidade, os itens misturados, que são elementos igualmente importantes. Balaté apresenta possíveis ligações com sítios mais distantes, tais como Kwatta e Hertenrits, baseado apenas em poucos fragmentos possivelmente originários de trocas. A falsa alça e o filete aplicado ondulado (Figura 5L) representam os elementos decorativos que também são encontrados nos conjuntos de Hertenrits tardio e Kwatta (Boomert, 1980, p. 75, figura 4.6; Versteeg, 2003, p. 117, figura 6.24, p. 118, figura 6.27 e p. 143, figura 7.5 ).

\footnotetext{
12 O baixo rio Maroni tem sido visitado pelos europeus desde o fim do século XVI.
}

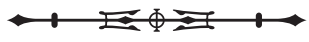


Tabela 6. Datações radiocarbônicas dos sítios na Guiana Francesa: AM 41, Awala, Angoulême, La Pointe de Balaté, Bois Diable/La Sablière, Crique Sparouine, Chemin Saint-Louis, K-VIII, Sable Blanc Est, Sainte Agathe, Saut Saillat, Tania, Wayabo e os sítios do Suriname mencionados no texto.

(Continua)

\begin{tabular}{|c|c|c|c|c|}
\hline Sitío & Numero do Laboratório & \multicolumn{2}{|c|}{ Datação convencional A.P. } & Referência \\
\hline AM 41 & KIA-33862 & 1000 & 35 & van den Bel (2009) \\
\hline Angoulême & LY-4949 & 440 & 30 & Gassies e Dauphin (2013) \\
\hline Awala, Alatou 1 & ETH-40724 & 805 & 30 & Coutet (2011) \\
\hline Awala, Alatou 2 & ETH-41721 & 885 & 40 & Coutet (2011) \\
\hline Awala, Alatou 3 & ETH-41722 & 130 & 35 & Coutet (2011) \\
\hline Awala, Alatou 3 & ETH-41721 & 170 & 60 & Coutet (2011) \\
\hline Awala, Tukuwali & PA-1945 & 865 & 40 & Janin (2002) \\
\hline Bois Diable/La Sablière & BETA-254054 & 750 & 40 & Mckey et al. (2010) \\
\hline Bois Diable/La Sablière & OBDY-794 & 510 & 40 & Rostain (1994) \\
\hline Chemin Saint-Louis & KIA-36135.1 & 5030 & 130 & van den Bel (2008a) \\
\hline Chemin Saint-Louis & POZ-36925 & 730 & 30 & van den Bel (2012) \\
\hline Chemin Saint-Louis & POZ-30945 & 885 & 30 & van den Bel (2012) \\
\hline Chemin Saint-Louis & POZ-30957 & 1020 & 30 & van den Bel (2012) \\
\hline Chemin Saint-Louis & POZ-36929 & 1050 & 30 & van den Bel (2012) \\
\hline Crique Sparouine & KIA-32394 & 585 & 25 & van den Bel (2010) \\
\hline Crique Sparouine & KIA-32396 & 750 & 25 & van den Bel (2010) \\
\hline Crique Sparouine & KIA-32395 & 905 & 25 & van den Bel (2010) \\
\hline Crique Sparouine & KIA-33555 & 1045 & 20 & van den Bel (2010) \\
\hline K-VIII & BETA-254058 & 1010 & 40 & McKey et al. (2010) \\
\hline La Pointe de Balaté & POZ-35845 & 130 & 30 & Briand (2015) \\
\hline La Pointe de Balaté & POZ-35841 & 195 & 30 & Briand (2015) \\
\hline La Pointe de Balaté & POZ-35840 & 420 & 30 & Briand (2015) \\
\hline La Pointe de Balaté & POZ-35842 & 780 & 30 & Briand (2015) \\
\hline La Pointe de Balaté & POZ-35847 & 825 & 30 & Briand (2015) \\
\hline La Pointe de Balaté & POZ-35846 & 835 & 30 & Briand (2015) \\
\hline La Pointe de Balaté & POZ-35844 & 905 & 30 & Briand (2015) \\
\hline La Pointe de Balaté & POZ-35848 & 1616 & 30 & Briand (2015) \\
\hline La Pointe de Balaté & POZ-35843 & 2075 & 30 & Briand (2015) \\
\hline La Pointe de Balaté & KIA-36134.2 & 325 & 25 & Briand (2015) (caco) \\
\hline La Pointe de Balaté & KIA-36135.2 & 2325 & 25 & Briand (2015) (caco) \\
\hline La Pointe de Balaté & KIA-36136 & 795 & 25 & van den Bel (2008b) \\
\hline La Pointe de Balaté & KIA-36137 & 835 & 35 & van den Bel (2008b) \\
\hline La Pointe de Balaté & KIA-36134.1 & 55 & 35 & van den Bel (2008b) \\
\hline Sable Blanc Est & LY-4961 & 825 & 30 & Mckey et al. (2010) \\
\hline Sable Blanc Est & LY-4960 & 880 & 30 & McKey et al. (2010) \\
\hline
\end{tabular}


Tabela 6.

(Conclusão)

\begin{tabular}{|c|c|c|c|c|}
\hline \multirow{2}{*}{$\frac{\text { Sitío }}{\text { Sable Blanc Est }}$} & \multirow{2}{*}{$\begin{array}{c}\text { Numero do Laboratório } \\
\text { LY-4959 }\end{array}$} & \multicolumn{2}{|c|}{ Datação convencional A.P. } & \multirow{2}{*}{$\frac{\text { Referência }}{\text { McKey et al. (2010) }}$} \\
\hline & & 900 & 30 & \\
\hline Sable Blanc Est & LY-4960* & 920 & 30 & Mckey et al. (2010) \\
\hline Sable Blanc Est & LY-4958 & 925 & 30 & McKey et al. (2010) \\
\hline Sable Blanc Est & LY-4956 & 955 & 30 & Mckey et al. (2010) \\
\hline Sable Blanc Est & LY-4958 & 990 & 30 & Mckey et al. (2010) \\
\hline Sainte Agathe & OBDY-796 & 380 & 35 & Rostain (1994) \\
\hline Sainte Agathe & UGAMS-4567a & 980 & 25 & Samuelian (2009) \\
\hline Sainte Agathe & UGAMS-4567b & 505 & 80 & Samuelian (2009) \\
\hline Sainte Agathe & UGAMS-4568 & 540 & 25 & Samuelian (2009) \\
\hline Saut Saillat & KIA-31239 & 360 & 25 & Hildebrand (2008) \\
\hline Saut Saillat & KIA-31242 & 390 & 20 & Hildebrand (2008) \\
\hline Saut Saillat & KIA-31240 & 425 & 20 & Hildebrand (2008) \\
\hline Tania & KIA-26021 & 675 & 75 & van den Bel (2004) \\
\hline Tania & KIA-26020 & 1535 & 25 & van den Bel (2004) \\
\hline Tania & KIA-26022 & 410 & 20 & van den Bel (2004) \\
\hline Wayabo, Sítio 1 & POZ-30850 & 395 & 30 & Briand (2011) \\
\hline Wayabo, Sítio 18 & POZ-30853 & 1160 & 30 & Briand (2011) \\
\hline Wayabo, Sítio 25 & POZ-30854/5 & 830 & 30 & Briand (2011) \\
\hline Wayabo, Sítio 25 & POZ-33044 & 905 & 30 & Briand (2011) \\
\hline Wayabo, Sítio 25 & POZ-33045 & 935 & 30 & Briand (2011) \\
\hline Wayabo, Sítio 26 & POZ-33046 & 860 & 30 & Briand (2011) \\
\hline Wayabo, Sítio 9 & POZ-30852 & 2035 & 35 & Briand (2011) \\
\hline Commetawane & GrN-4414 & 1310 & 45 & Versteeg (1980) \\
\hline Boekoe Kreek 2 & GrN-7936 & 975 & 50 & Versteeg (1980) \\
\hline Bigiston & GrN-4240 & 410 & 60 & Versteeg (1980) \\
\hline Chrisitaankondre & GrN-4241 & 440 & 50 & Versteeg (1980) \\
\hline Moricokreek & GrN-2321 & 455 & 65 & Versteeg (1980) \\
\hline
\end{tabular}

Finalmente, Saint-Louis e Balaté claramente compartilham a ocupação Koriabo, evidenciada pelos potes tóricos altamente decorados, do Grupo L para Saint-Louis e SM IV para Balaté. Com relação a Saint-Louis, duas ocupações do período cerâmico tardio foram propostas, o que se reflete em duas diferentes indústrias: a cerâmica Koriabo e a Barbakoeba. É interessante que apenas uma única vasilha Koriabo datada (EC 7; Figura 5A) foi encontrada na feição 89 em Balaté e resultou em uma datação radiocarbônica por volta do século XV, o que está de acordo com as datações obtidas para os sítios Bigiston, Christiaankondre e Morico Kreek (Versteeg, 2003), no Suriname, e Tania (van den Bel, 2004), Saut-Saillat (Hildebrand, 2008) e Angoulême (Gassies e Dauphin, 2013), na Guiana Francesa, enquanto outras feições características (Feições 123, 142 e 143) são datadas entre 1100 e 1300 A.D. ou no período histórico (F 115), das quais o último resultado pode ser errôneo. Além disso, 
esta ambiguidade entre Koriabo, as cerâmicas locais e a cronologia também é encontrada em Crique Sparouine (van den Bel, 2010).

\section{O CEMITÉRIO AM 41}

A necrópolis AM 41 do período cerâmico tardio está localizada em uma barreira pleistocênica arenosa a oeste da aldeia moderna de Iracoubo e foi escavada em 2006 por membros do INRAP (van den Bel, 2006, 2009). Ao norte deste cemitério particular, estão localizados os sítios habitacionais de Sable Blanc Est (SBE), os quais foram escavados por membros do Projeto Earthmovers (Rostain et al., 2008). Este sítio-habitação estende-se pela Rodovia Nacional 1 (Route Nationale 1, RN 1), apresentando mais urnas funerárias e áreas habitacionais do período cerâmico tardio (LCA), conforme foi evidenciado por uma outra prospecção mecânica realizada pelo INRAP mais recentemente (Briand, 2012)13.

O inventário aqui apresentado reúne as cerâmicas encontradas nas zonas A e B da necrópolis situada na parcela AM 41 (van den Bel, 2009; Figura 6). Este estudo cerâmico está baseado em formas inteiras e em uma variedade de perfis de borda, que representam 74 elementos cerâmicos maiores do que $5 \mathrm{~cm}^{2}$ ou elementos constituintes (EC). Estes elementos diagnósticos compreendem o material cerâmico obtido de feições e que pertencem tanto à Zona $\mathrm{A}(\mathrm{N}=41)$ quanto $\mathrm{B}(\mathrm{N}=$ 33), revelando maior quantidade de cerâmica na Zona A. A contagem de elementos constituintes apresenta 15 indivíduos decorados e 33 vasilhas completas, correspondendo a 62 bordas, 40 bases e cinco assadores $(N=107)$. Bordas reutilizadas também foram registradas: o que quer dizer, a parte inferior de uma vasilha quebrada na carena foi retrabalhada e serviu como uma vasilha aberta. É notável que este tipo tenha sido registrado apenas na Zona B.
A pasta contém diferentes elementos não plásticos, que devem ter sido usados como tempero pelos ceramistas. No total, quatro modos foram observados: um mineral, outro vegetal, outro misturado e outro caco moído, dos quais o último é claramente o mais popular (80\%). A atribuição de um modo particular de tempero foi baseada na presença dominante de um material específico não plástico. Por exemplo, fragmentos temperados com caco moído também contêm uma porção menor de areia e/ou de cinzas de casca de árvore, mas a predominância do caco moído demonstra que este era um elemento mais importante. Tecnicamente, é mais exato se referir a estas pastas como tempero misturado, mas uma análise microscópica mais detalhada será necessária para determinar sua quantificação. Fragmentos temperados com kwepi (caraipé) são raros ( $N=1)$, mas, conforme mencionado, o kwepi foi observado em quantidades menores presente nas misturas de tempero, não sendo considerado um agente significativo neste sítio (Tabela 7).

Métodos de queima também foram determinados e agrupados em quatro principais cores: vermelho,

Tabela 7. Distribuição de tempero do sítio AM 41.

\begin{tabular}{c|c|c|c|c}
\hline \multicolumn{2}{c|}{} & Descrição & Modo & N \\
\hline \multirow{2}{*}{$\begin{array}{c}\text { Mineral } \\
(7 \%)\end{array}$} & 1 & Areia & 11 & 5 \\
\cline { 3 - 5 } & & $\begin{array}{c}\text { Areia }+ \text { mica } \\
+ \text { minerais }\end{array}$ & 13 & 0 \\
\hline $\begin{array}{c}\text { Vegetal } \\
(1 \%)\end{array}$ & 2 & Carvão + minerais & 21 & 0 \\
\hline & 3 & Cinzas & 22 & 12 \\
\hline $\begin{array}{c}\text { Mistura } \\
(12 \%)\end{array}$ & 31 & 31 & 5 \\
\hline $\begin{array}{c}\text { Caco moído } \\
(80 \%)\end{array}$ & 4 & Cinzas + minerais & 32 & 4 \\
\hline \multicolumn{2}{|c|}{ Caco moído } & 41 & 59 \\
\hline
\end{tabular}

\footnotetext{
${ }^{13}$ Quando Jérôme Briand (INRAP) conduziu esta prospecção ao longo do RN 1, próximo a Iracoubo, descobriu que o número da parcela da necrópolis era, de fato, AM 41, e não AM 43, conforme fornecido pelo Estado como o número oficial do lote (Briand, 2012, p. 23).
}

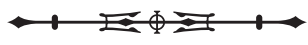




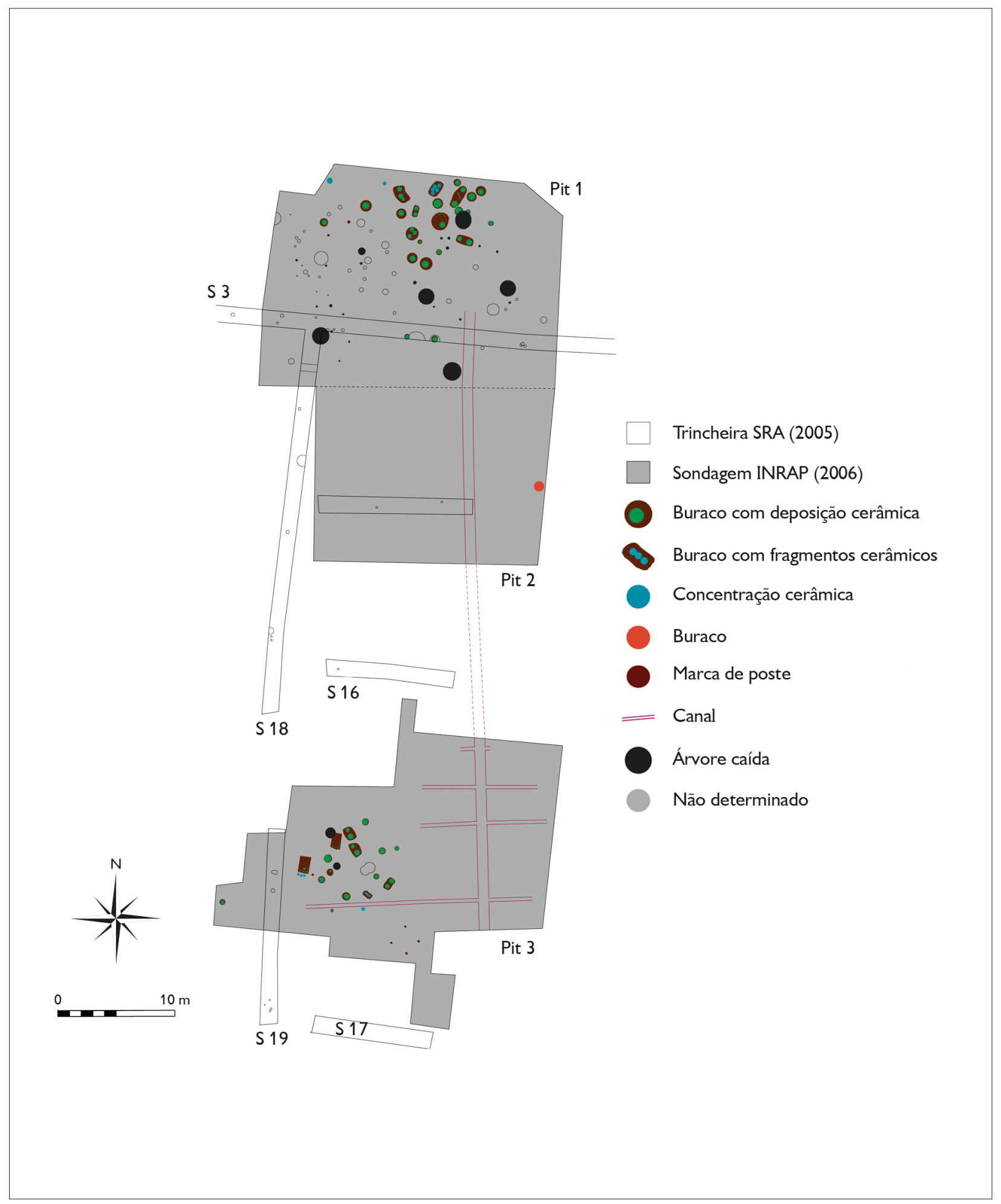

Figura 6. Plano de escavação do sítio AM 41.

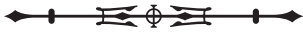


laranja a marrom, centro escuro (cinza/preto) com as margens mais claras e cor escura em todo o núcleo (cinza ou preto) (Rye, 1981, p. 116, figura 104). As duas últimas cores são o resultado de uma técnica de queima em ambiente redutor (63\%), que é predominante, enquanto as primeiras refletem ambiente oxidante (7\%) e representam a técnica de queima menos observada. Em suma, as cerâmicas temperadas com caco moído são preferivelmente queimadas em ambiente redutor (48\%).

\section{As bordas}

A diversidade de perfis de borda observados durante este estudo tornou possível criar oito séries modais (SM I-VIII) (Tabela 8, Figuras 7-8). Os principais elementos diagnósticos dos perfis de borda, tendo em vista sua morfologia, são retilíneos, côncavos e convexos, pertencentes a vasilhas abertas e vasilhas restritas (SM I-III e SM V-VI), havendo ainda a presença de carenas e gargalos (SM IV e SM VIII, respectivamente). As séries mais importantes são SM I-III e SM V, enquanto que outras séries são claramente menos importantes. $\bigcirc$ tratamento labial específico apenas foi registrado para
SM III e nas vasilhas reutilizadas já mencionadas (SM 0). A espessura, o diâmetro, a queima, a decoração e a pasta foram registrados para cada elemento constituinte. Vasilhas abertas são dominantes nesse conjunto cerâmico (72\%).

Tabela 8. Séries modais de bordas (SM I-VIII) do sítio AM 41. Legendas: $A$ = aberta; $R$ = restrita (fechada); $X$ = não determinada.

\begin{tabular}{c|c|c|c}
\hline SM & Forma & Descrição & N \\
\hline Ia & A & Perfil retilíneo & 15 \\
\hline Ib & A & Perfil convexo & 9 \\
\hline II & R & Perfil convergente & 12 \\
\hline III & A & Demarcação do lábio no interior & 5 \\
\hline IVa & A & Potes matados & 2 \\
\hline IVb & A & Vasilhas matadas & 4 \\
\hline V & $A$ & Vasilhas em forma de barco & 3 \\
\hline VI & $A$ & Tigelas & 2 \\
\hline VII & $A$ & Pratos & 2 \\
\hline VIIlla & R & Garrafas (pequenas) & 2 \\
\hline VIIlb & R & Vasilhas com gargalos (grandes) & 3 \\
\hline 0 & $X$ & Vasilhas reutilizadas & 3 \\
\hline & & & Total: 62 \\
\hline
\end{tabular}

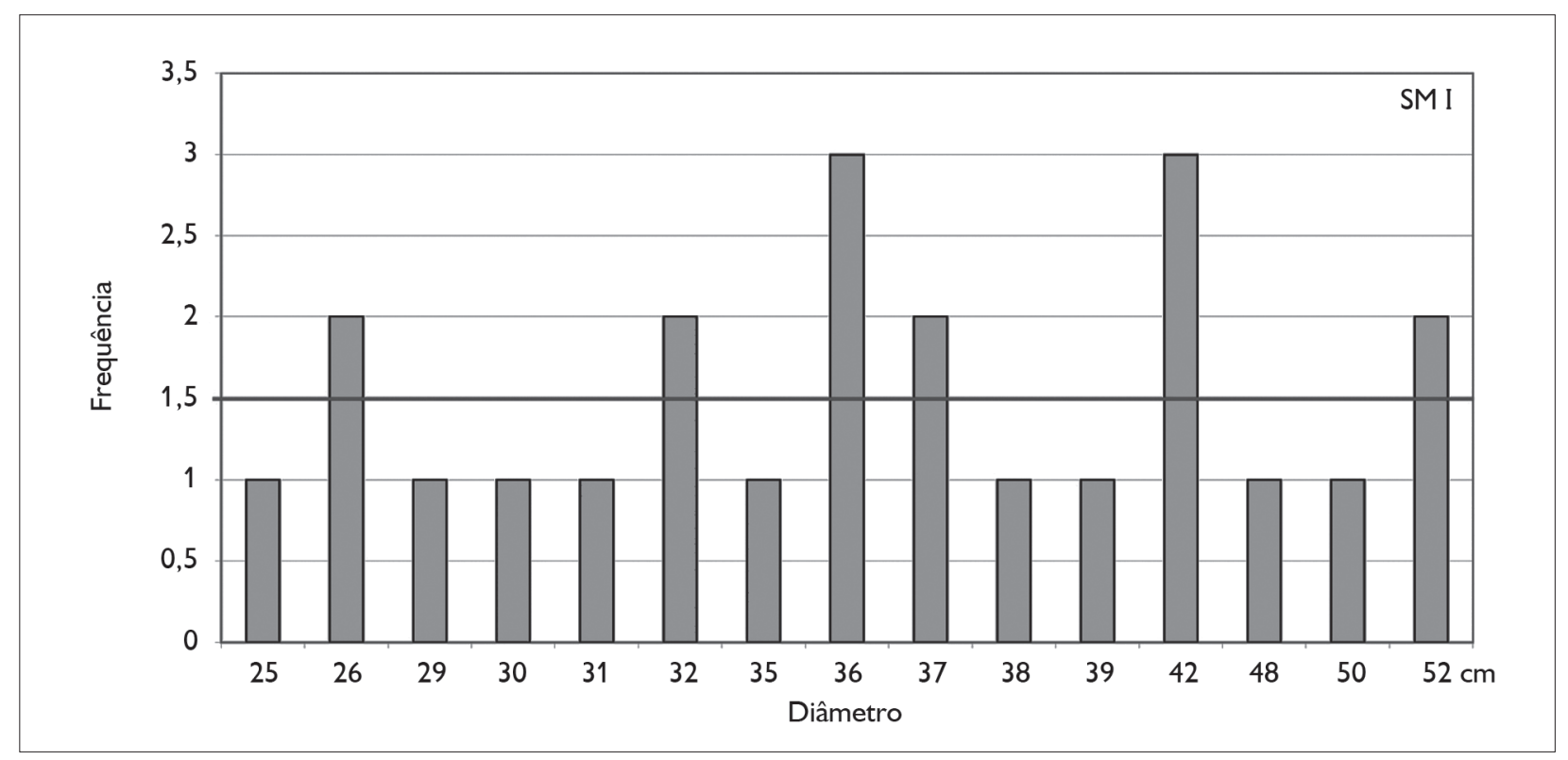

Figura 7. Frequência dos diâmetros de SM I do sítio AM 41.

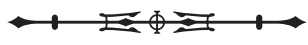




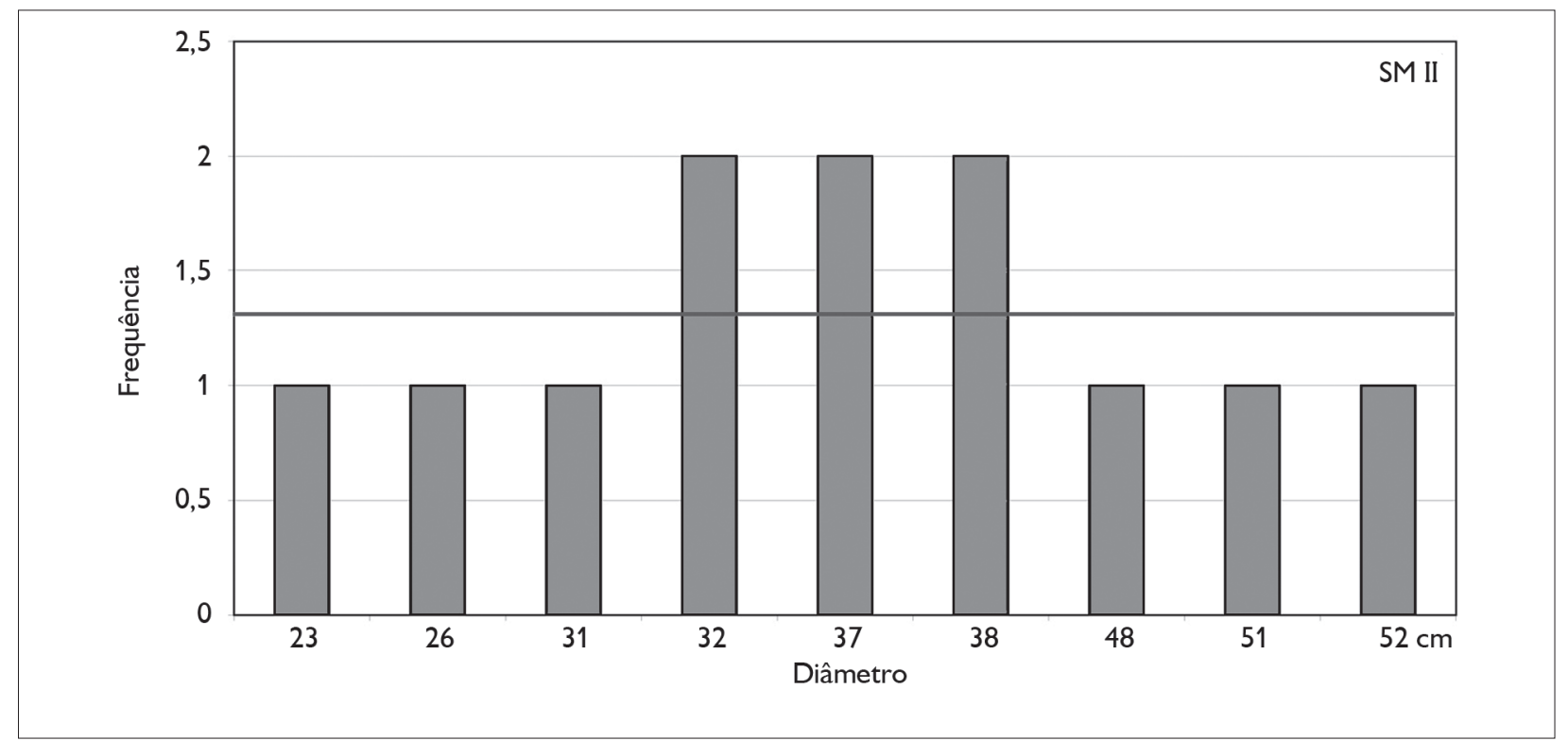

Figura 8. Frequência dos diâmetros de SM II do sítio AM 41.

\section{SM I}

Essa série representa vasilhas abertas com um perfil retilíneo $(N=15)$ ou levemente convexo $(N=9)$, sendo a mais popular das séries $(N=24,39 \%)$. Ela representa quase metade de todos os elementos constituintes, sendo considerada o produto mais destacado deste sítio. As partes terminais dos lábios são arredondadas (54\%), planas (25\%) ou apontadas (21\%) e as espessuras das paredes variam entre 6 e $11 \mathrm{~mm}$. Os diâmetros variam entre 15 e $52 \mathrm{~cm}$. Quando se toma a média $(36 \mathrm{~cm}) \mathrm{da}$ soma do número mais frequente como um elemento possível de discriminação observa-se vários picos ou altas frequências destas séries: um pico de 26, 32, 36 e $37 \mathrm{~cm}$, mas também de 42 a $52 \mathrm{~cm}$ (Figura 9). Estes picos refletem diferentes tamanhos de vasilhas de morfologias similares, que são dominados por diâmetros com cerca de $25 \mathrm{~cm}$ de circunferência.

A importância do caco moído como tempero é notável para estas séries (83\%) e, em combinação com a técnica de queima reduzida (58\%), ele é o elemento mais significante registrado para este sítio. Todas as outras combinações possíveis de tempero e queima são menos relevantes para esta série. $\bigcirc$ interessante é que ela não apresenta qualquer tipo de decoração. Este fato, bem como outros traços já mencionados - por exemplo, antiplástico de caco moído, técnica de queima e grandes vasilhas -, sugere que ela servia como cerâmica de uso doméstico, demostrando uma produção bastante homogênea.

\section{SM II}

Essa é a segunda série, menos importante do que SM I, mas, ainda assim, mais destacada do que as séries remanescentes. Ela compreende vasilhas restritas com perfis de bordas convergentes ou altamente convexos ( $N=12,19 \%)$. Os lábios são arredondados (75\%), apontados (16\%) ou planos (8\%), enquanto a espessura da parede varia entre 7 e $12 \mathrm{~cm}$. Os diâmetros variam entre 23 e $52 \mathrm{~cm}$, e o pico de frequência é observado entre 32 e $28 \mathrm{~cm}$, refletindo a predominância de vasilhas cerâmicas com grandes diâmetros, o que mostra consistência na manufatura delas (Figura 10). A predominância da pasta com caco moído é evidente (75\%), assim como a queima reduzida (75\%). 


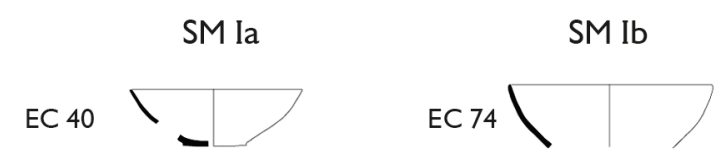

EC 36
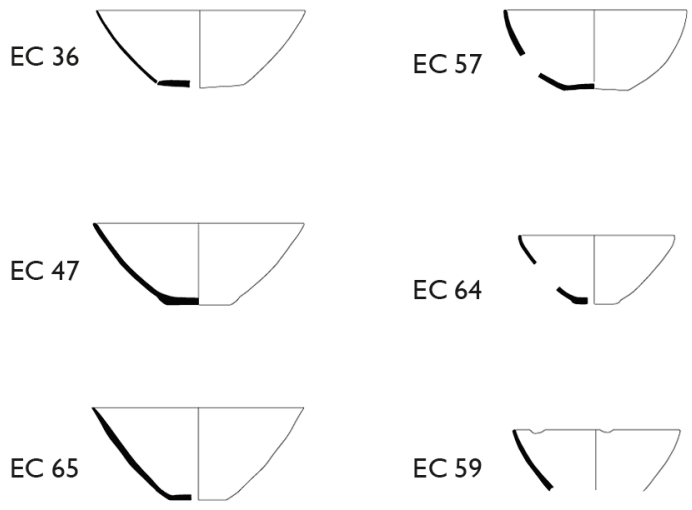

EC 63
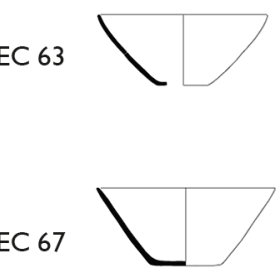

EC $41 \longmapsto$
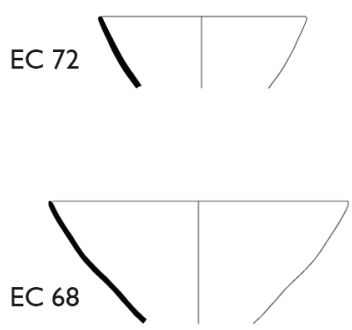
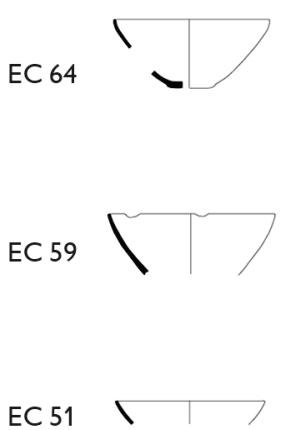

EC 39

EC 56

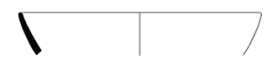

SM VIIlb

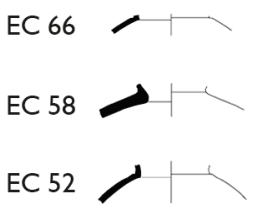

EC $51>$
SM III

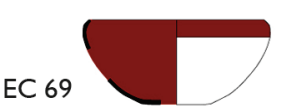

EC 61
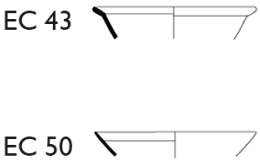

EC 70

EC 38
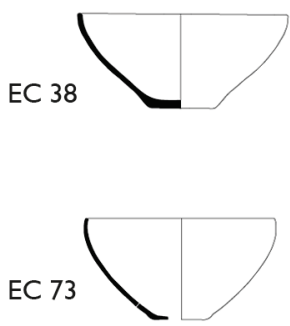

$\mathrm{SM} \mathrm{IVb}$

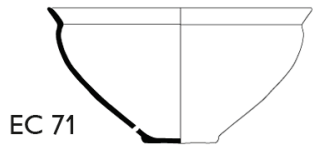

SMV

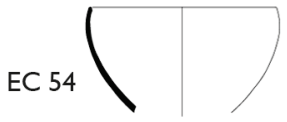

EC $46 \searrow T$

Zona A

$5 \mathrm{~cm}$

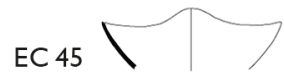

Figura 9. Desenhos de cerâmicas encontradas na Zona A do sítio AM 41.

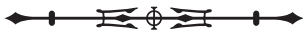




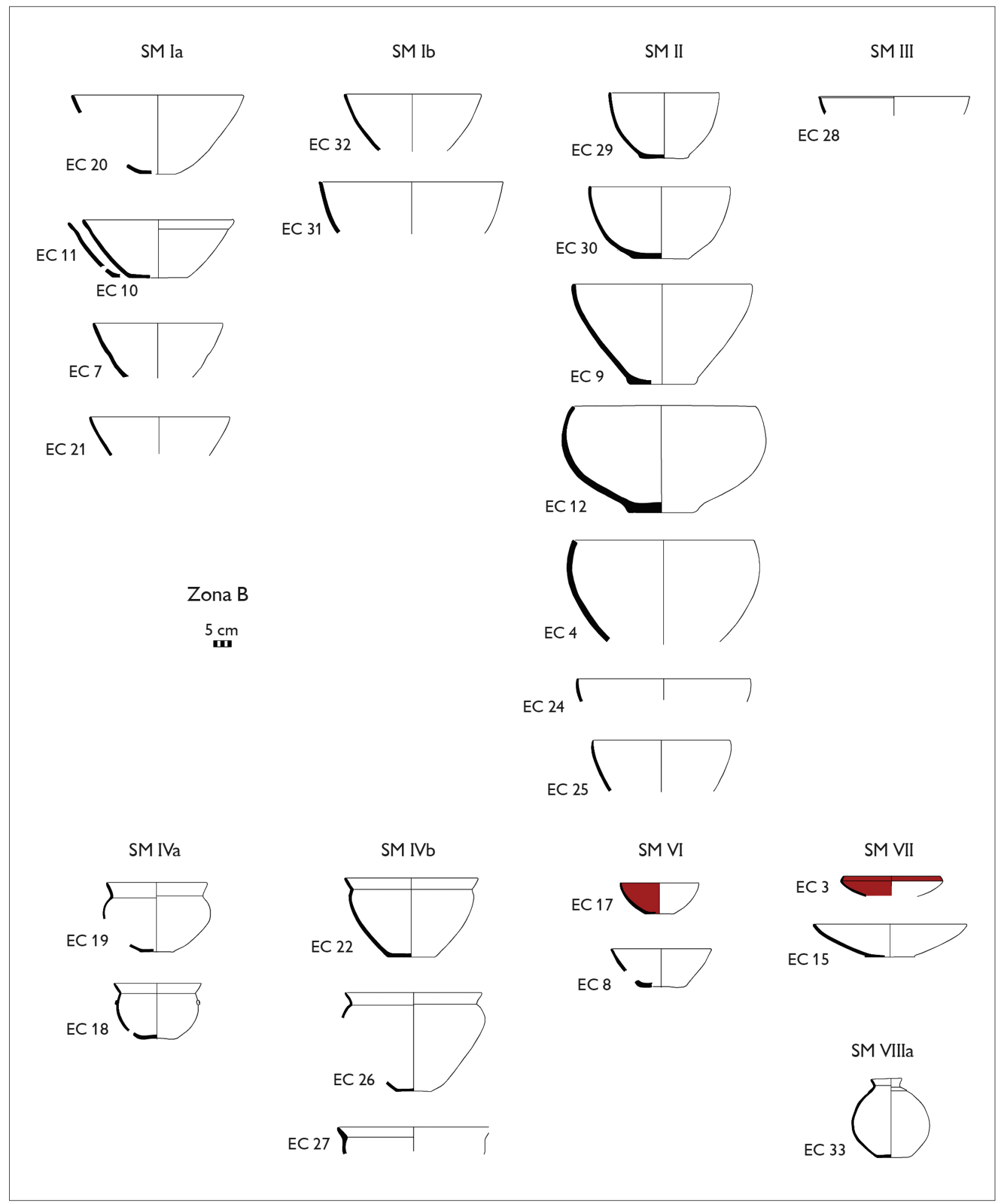

Figura 10. Desenhos de cerâmicas encontradas na Zona B do sítio AM 41.

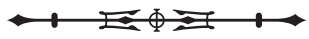


Em contraste com as séries dominantes, esta segunda possui três vasilhas decoradas, das quais duas apresentam engobo vermelho. Em uma, o engobo vermelho foi aplicado em ambas as faces, enquanto na outra apenas na face externa, além de outra adornada com um aplique modelado de cabeça dupla. Embora o engobo vermelho seja um modo comum de decoração, este exemplar modelado (EC 35) é notável e difere claramente do resto do material. Mais ainda, seu diâmetro é bem pequeno $(23 \mathrm{~cm})$ comparado à média desta série, assim como é a pasta temperada com areia ( $N=11)$. De qualquer forma, esta série é muito homogênea, sendo bastante significativa para este sítio.

\section{SM III, SM IV E SM VIII}

Essas são séries minoritárias comparadas às duas previamente discutidas. Entretanto, elas são um pouco mais populares do que SM $\vee$ a SM VII e também mostram morfologias altamente reconhecíveis. A morfologia específica de cada série - respectivamente inflexão, carena e gargalo - torna cada uma delas diferente. Para SM IV, foi possível distinguir a altura da vasilha, resultando em pequenos potes (SM IVa) e grandes vasilhas (SM IVb). Para SM VIII, foram identificadas diferenças em tamanho, resultando em pequenas garrafas (SM VIIla) e jarros grandes com gargalos (SM VIIIb). SM III apresenta uma vasilha com engobo vermelho no interior, enquanto as garrafas de SM VIIla possuem uma camada extra de argila aplicada na base do gargalos.

As séries SM IV não apresentam qualquer elemento decorado. Entretanto, sua pasta é misturada com areia e difere do tempero exclusivo de caco moído presente nas séries SM III e SM VIII, revelando uma singularidade peculiar destas séries. As séries remanescentes (SM V-VII e SM 0) são as menos populares, consistindo em sete indivíduos, com cada um deles representando distintas formas de vasilhas, tais como vasilhas abertas elipsoides (em forma de barco), tigelas e pratos, respectivamente. Apesar da importância menor em números, todas as séries são temperadas com caco moído e possuem ao menos um indivíduo com decoração de engobo vermelho. A vasilha aberta elipsoide (em forma de barco), com engobo vermelho (EC 53, F 65 da Zona A), é notável. Além do engobo vermelho aplicado no interior da parede, esse exemplar também apresenta um aplique modelado de cabeça dupla, colocado na parte mais alta da borda (ver também EC 35). Finalmente, SM 0 representa a parte mais baixa de vasilhas quebradas, das quais o limite do corpo foi alisado para servir novamente como uma vasilha (por exemplo, SM Ia).

\section{As bases}

Os perfis de base consistem em 40 indivíduos ou 37\% do total da contagem de elementos constituintes. Estes podem ser divididos em sete séries modais (Tabela 9), os quais têm sido definidos de acordo com a morfologia: bases planas (SM 1-3, 70\%), côncavas (SM 4-6, 28\%) e bases anelares (SM 7, 2,5\%), das quais as bases planas são as menos dominantes. Perfis com apêndices ou com pedestais são os mais populares, com 48\%. Tem-se notado que as bases quase sempre mostram traços de queima secundária, resultando em exemplares de base fragmentados e erodidos pelo fogo, tais como o EC 9, 19 e 42.

Uma subdivisão deve ser feita para as bases planas ( $N=28$ ) de acordo com o ângulo e a forma de colocação do primeiro rolete; bases planas com perfil convexo (SM 1, 14\%), com um perfil direto (SM 2 e SM 2a, 38\%), e bases planas com um perfil com pedestal (SM 3, 63\%). A pasta contendo caco moído (79\%) é dominante nesta série, em

Tabela 9. Séries modais de bases (SM 1-7) do sítio AM 41.

\begin{tabular}{c|c|c|c}
\hline SM & Forma & Perfil & N \\
\hline 1 & Plana & Convexo & 4 \\
\hline 2 & Plana & Retilíneo & 9 \\
\hline 3 & Plana & Apendicular & 15 \\
\hline 4 & Côncava & Retilíneo & 4 \\
\hline 5 & Côncava & Apendicular & 4 \\
\hline 6 & Côncava & Convexo & 3 \\
\hline 7 & Anelar & & 1 \\
\hline \multicolumn{3}{|c}{} & \\
\hline
\end{tabular}

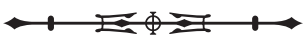


combinação com a técnica de queima redutora. A maior parte das bases possui um diâmetro variando entre 6 e 12 $\mathrm{cm}$, e dois maiores de 16 e $18 \mathrm{~cm}$. A espessura varia entre 8 e $18 \mathrm{~mm}$, e uma mais espessa é de $21 \mathrm{~mm}$. Parece não existir nenhuma relação clara entre tempero, diâmetro e espessura.

Duas bases possuem engobo vermelho no interior. As bases côncavas ( $N=11)$ foram subdivididas em três grupos similares: bases côncavas com um perfil direto (SM 4, 36\%), com um perfil em pedestal (SM 5, 36\%) e aquelas com um perfil convexo (SM 6, 28\%). A espessura destas bases varia entre 6 e $18 \mathrm{~mm}$, e o diâmetro varia entre 8 e $13 \mathrm{~cm}$, com um diâmetro maior de $24 \mathrm{~cm}$. O caco moído é o elemento mais popular utilizado como antiplástico (81\%), em combinação com uma técnica de queima redutora. Três bases receberam um engobo vermelho no interior. Finalmente, apenas uma base anelar foi registrada (EC 60), que possui $15 \mathrm{~cm}$ de diâmetro e é temperada com caco moído. É possível concluir que estas bases reflitam o mesmo padrão dos perfis de borda; o domínio do tempero de caco moído e o engobo vermelho como decoração, enquanto as bases em pedestal podem representar uma característica particular ou marcador cultural deste conjunto.

\section{Os assadores}

Apenas cinco bordas de assadores foram detectadas nesse conjunto. Assadores completos ou metades deles foram usados com objetos na posição vertical, nas suas laterais, para criar um efeito de parede nas estruturas retangulares (F 21 na Zona B e F 70 e F 95 na Zona A). A pasta consiste em caco moído processado em fragmentos espessos, e a espessura varia entre 22 e 28 mm, enquanto os diâmetros são de cerca de $60 \mathrm{~cm}$. Um assador pôde ser medido com precisão (EC 1: $82 \mathrm{~cm}$ ), uma vez que foi encontrado completo na estrutura F 21, Zona B.

\section{Os modos de decoração}

Esse conjunto cerâmico tem pouca decoração ( $N=11)$ : sete vasilhas com engobo vermelho; duas com apliques modelados de cabeças duplas; e duas com reforço na parte inferior, ao redor do gargalo, representando cerca de 10\% do total do número de indivíduos. O repertório decorativo é mais simples e consiste principalmente na aplicação uniforme de engobo vermelho (64\%), tanto no interior quanto em ambas as faces da vasilha. Quando aplicado à parte externa, apenas a parte superior é pintada, formando uma banda com engobo vermelho ao redor da vasilha. É notável a ausência de incisões, ponteados e ungulados, bem como de outros modos com coloração, a exemplo do branco, branco sobre vermelho e/ou pintura policrômica.

\section{Síntese de AM 41}

Ao discutir esse conjunto cerâmico particular, é importante apontar que toda cerâmica foi encontrada junta, como parte de uma ampla zona funerária, situada em uma elevação natural, que é claramente separada da suposta aldeia, situada ao norte. A cerâmica foi encontrada em duas zonas, nas quais as vasilhas cerâmicas foram depositadas em posições distintas e de maneiras diferentes. Embora nenhum osso humano, queimado ou não queimado, tenha sido observado nas estruturas ou nos potes, é provável que estas cerâmicas representem vasilhas já existentes, usadas em contexto doméstico e reutilizadas durante rituais funerários (van den Bel, 2009).

A síntese tipológica está baseada em 62 elementos de bordas, incluindo 33 vasilhas completas. $\bigcirc$ registro morfológico declina com relação às vasilhas simples hemisféricas com bordas retilíneas ou convergentes (SM I e II). Menos populares são as vasilhas hemisféricas com lábio demarcado no interior (SM III), vasilhas com carenas (SM IV), garrafas (SM VIIla) e jarros (SM VIIlb), vasilhas elipsoides (em forma de barco) (SM IV), pequenas tigelas (SM V) e pratos (SM VI). A decoração é rara, sendo composta pela aplicação de engobo vermelho uniforme no interior e/ou na parede externa, pelo espessamento ao redor dos gargalos e os apliques de cabeças duplas. Traços característicos onipresentes são as bases em pedestal, temperadas com caco moído e com a queima reduzida, o qual representa um conjunto homogêneo no espaço e no tempo. 
É evidente que os resultados deste inventário cerâmico devem ser comparados ao estudo da escavação do Projeto Earthmovers, em Sable Blanc Est (Rostain et al., 2008), situado ao norte do sítio AM 41. Entretanto, um inventário cerâmico completo nunca foi realizado para este sítio, e o relatório apenas afirma que "desde o início das prospecções o estilo da cerâmica pareceu claramente ser Barbakoeba", porque "a natureza e qualidade da pasta, do tratamento de superfície, da espessura da parede e a decoração esparsa não deixa dúvidas sobre a sua origem" (Rostain et al., 2008, p. 37), sem, contudo, revelar qualquer quantificação ou desenhos. Esta afirmativa é apresentada quando os autores se referem a um "estudo preliminar" ou rápido sobre o material cerâmico, no qual roletes não alisados e apêndices modelados parecem ser modos dominantes de decoração do material escavado (Rostain et al., 2008, figuras 31 e 32). Em resumo, não é possível comparar os dois conjuntos, no que tange à morfologia, pasta e modos de decoração. Podemos apenas nos basear na mera presença de certos modos de decoração, os quais não foram quantificados nas escavações de Sable Blanc Est.

Felizmente, Claude Coutet (2009, p. 326-351) selecionou 881 fragmentos destas escavações de 2007 para sua análise tecnológica, provenientes de diferentes feições e de coletas de superfície. Ela defendeu a onipresença de caco moído ou deste elemento misturado a outros, como tempero, em combinação com a queima reduzida e bases em pedestal. A autora propôs sete tipos, os quais correspondem a várias séries propostas para AM 41 (Tabela 10), sugerindo a presença de formas de vasilhas similares e a contemporaneidade de ambos os sítios (Coutet, 2009, p. 351). Deste ponto de vista, não se pode deixar de reconhecer a presença de apliques de cabeças duplas, mas é preciso negar a presença de roletes aparentes ou sem alisamento em AM 41. Finalmente, o EC 17 de AM 41 parece a vasilha elipsoide (em forma de barco) com engobo vermelho, encontrada na feição 84 em Sable Blanc Est (Rostain et al., 2008, p. 29, figura 26).
Tabela 10. Comparação entre os tipos de Sable Blanc Est, conforme definido por Coutet (2009), e as séries modais do sítio AM 41. Legenda: $X=$ não determinada.

\begin{tabular}{c|c}
\hline Tipo & SM \\
\hline $1 \mathrm{a}$ & SM II \\
\hline $1 \mathrm{~b}$ & SM V \\
\hline 2 & SM IV \\
\hline $3 a$ & SM I \\
\hline $3 \mathrm{~b}$ & SM III/SM VII \\
\hline $4 a$ & SM I \\
\hline $4 b$ & SM I \\
\hline $4 c$ & SM VI \\
\hline 5 & SM VIII \\
\hline 6 & SM VIII \\
\hline 7 & SM II? \\
\hline 8 & $\times$ \\
\hline
\end{tabular}

Assim sendo, ambos os sítios possuem poucos elementos decorativos, os quais são comuns no litoral inteiro entre Hertenrits e Kourou.

Uma diferença importante é observada quando se comparam os sítios individualmente. Embora ambos tenham deposições cerâmicas, AM 41 representa um único sítio funerário, enquanto Sable Blanc Est parece ser um sítio misturado, revelando tanto feições habitacionais quanto funerárias, encontradas na mesma escavação. Além disso, os resultados das datações radiocarbônicas de Sable Blanc Est (sete datas no total de cinco fogueiras, uma área de lixeira e uma urna funerária) variam entre 700 AP e 950 AP (McKey et al., 2010, tabela S1), enquanto apenas AM 41 é mais antiga, anterior à área escavada de Sable Blanc Est.

Apesar da ausência de mais material arqueológico comparativo entre estes sítios, a separação geográfica de ambos permanece um fator importante e precisa de melhor elaboração. Dados complementares sobre essa questão são fornecidos pelo levantamento realizado pelo INRAP em 2011 ao longo do RN 1, entre Sable Blanc Est e a aldeia de Iracoubo (Briand, 2012). Esse levantamento 
revelou que o trecho inteiro da elevação pleistocênica ao longo desta estrada apresentou quase exclusivamente deposições cerâmicas com um campo gigante de urnas (Briand, 2012, p. 93). O inventário do material cerâmico exumado apresenta roletes, bordas unguladas, ponteados, engobo vermelho e apliques modelados, o que também tem sido observado em Sable Blanc Est. Entretanto, o levantamento também detectou pintura vermelha sobre branco, o que não ocorre nas escavações antes mencionadas (Briand, 2012, figuras 89-92), mas está presente em Bois Diable/La Sablière (ver anteriormente) e Sainte Agathe (Wack, 1990; Samuelian, 2009). As formas (Briand, 2012, figuras 87-88) mostram características similares às encontradas em AM 41: um gargalo espesso, vasilhas abertas similares às de SM la, e vasilhas elipsoides (em forma de barco), todas com pasta contendo caco moído. Briand (2012, p. 81) atribui a cerâmica à "cultura Barbakoeba e à tradição Arauquinoide".

Outro sítio do período cerâmico tardio apresentando modos de decoração similares é Bois Diable/La Sablière, localizado na margem arenosa holocênica da aldeia de Kourou. Este sítio foi escavado no início de 1990 (Barone-Visigalli e Prost, 1991; Thooris, 1994), bem como em 2008 e 2009, durante o Projeto Earthmovers (Rostain et al., 2009, 2010). De acordo com Rostain et al. (2010, p. 25), Bois Diable revelou cerâmicas atribuídas a dois diferentes complexos; algum material Barbakoeba, mas a maioria pode ser associada à ocupação Thémire tardia, conforme ele concluiu há 20 anos (Barone-Visigalli e Prost, 1991, p. 52)14. O último relatório contém um inventário cerâmico detalhado, elaborado por Rostain, sendo que $7 \%$ da cerâmica é decorada ( $N=1.306)$. Uma análise de 112 fragmentos cerâmicos permitiu identificar quatro tipos, baseados principalmente na pasta (caco moído, areia ou mica), mas também em três diferentes tipos de bordas e modos de decoração, entre os quais a pintura complexa em branco sobre vermelho; incisões verticais (cruzadas e paralelas), quadriláteros e triângulos são modos pouco observados (Rostain apud Barone-Visigalli e Prost, 1991, p. 31-33).

A análise cerâmica feita por Catherine Thooris (1994, p. 14-23) de 598 bordas e 150 bases confirmou a abundância de caco moído como tempero e a presença de modos similares de decoração, sugerindo uma vinculação dos complexos Kwatta e Barbakoeba do Suriname (Thooris, 1994, p. 26). Notadamente, os filetes aplicados e digitados, colocados logo abaixo da borda, os roletes aparentes e a modelagem biomorfa (olhos), ao invés de marcadores Barbakoeba, de acordo com Boomert (1993, p. 20, pranchas 14, 15 e 17), são importantes aspectos decorativos deste sítio. Formas dominantes de vasilhas são as abertas, com bordas côncavas e convexas, bem como as restritas, com bordas convexas, representando cerca de 2/3 do conjunto cerâmico (Boomert ,1993, p. 19).

Embora também não exista um inventário cerâmico ou análise nos relatórios do Projeto Earthmovers, para Bois Diable, Claude Coutet (2009, p. 297-325) selecionou 846 fragmentos cerâmicos para a análise de três tipos de concentrações e algumas feições. Sua análise confirmou a abundância de caco moído como tempero e do vermelho na pintura branco sobre vermelho (7\%), enquanto as incisões são raras - provavelmente devido à pré-seleção no campo. Coutet distinguiu dez tipos e confirmou a raridade das vasilhas restritas para este sítio, a abundância de tigelas abertas extrovertidas e pratos com lábios modelados (planos no interior e reforçados na face externa) (Tabela 11). Podemos apontar similaridades morfológicas entre vasilhas com gargalo da Zona B SM IV e aquelas encontradas em BPS 13 (Vacher et al., 1998, p. 225, pranchas 9.159, 161, 167, 168), BPS 172 (Vacher et al., 1998, p. 237, pranchas $26.106,108,109)$, mas também

\footnotetext{
${ }^{14}$ De acordo com a análise de Rostain, alguns fragmentos Koriabo, bem como o material temperado com kwepi, têm sido identificados em La Sablière (Barone-Visigalli e Prost, 1991, p. 52).
}

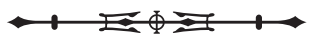


Tabela 11. Comparação sugerida para Bois Diable/La Sablière entre os tipos, conforme definido por Coutet (2009), e as séries definidas por Thooris (1994).

\begin{tabular}{c|c|c|c|c}
\hline Tipo & Bordas & Forma & Perfil & $\%$ \\
\hline 3,8 & B & A & Tangente & 1 \\
\hline 1,7 & D & A & Côncavo & 32 \\
\hline $2,5 a, 6$ & E & A & Retilíneo & 12 \\
\hline 9 & F & A (vertical) & Retilíneo & 9 \\
\hline & G & R & Côncavo & 5 \\
\hline & H & R & Retilíneo & 6 \\
\hline 4,10 & I & R & Convexo & 19 \\
\hline Coutet & Thooris & \multicolumn{3}{|l}{} \\
\hline
\end{tabular}

para as vasilhas abertas elipsoides (em forma de barco) em SM V, Zona A versus BPS 172 (Vacher et al., 1998, p. 236, prancha 25.99) 15 . Finalmente, fortes similaridades podem ser encontradas no EC 12, Zona A versus BPS 17.30 e 29 (Vacher et al., 1998, p. 230, prancha 16), que também representa um duplo enterramento em urna.

\section{REPENSANDO O PERÍODO CERÂMICO TARDIO DA GUIANA CENTRAL}

Quando se considera a análise anteriormente apresentada, podemos, de fato, confirmar que estes conjuntos pertencem à mesma área cultural, conforme já apontado por Coutet (2009, p. 435), "as formas são consideradas distintas para a cultura Barbakoeba e não foram sistematicamente encontradas em todos os sítios
[Barbakoeba] (tigelas de formato oval com vários lóbulos, pratos fundos com roletes não alisados)" ${ }^{m}$.

Desse modo, parece ser um verniz Barbakoeba que cobre a diversidade regional, a qual é materializada pelas vasilhas temperadas com caco moído com decoração escassa ${ }^{17}$. As vasilhas discutidas aqui têm predominantemente formas grandes abertas e/ou levemente restritas, caracterizadas por tigelas simples e/ou com bordas extrovertidas e bases em pedestal. Pequenos gargalos nos vasos globulares e pequenas tigelas pintadas de vermelho também são traços destes conjuntos. De um lado, esta homogeneidade aparente é enfatizada pela presença de urnas funerárias secundárias nas planícies oeste da Guiana Francesa, mas, por outro lado, a diversidade regional de modos de enterramento tende a revelar importantes diferenças locais.

Consequentemente, nessa seção final, apresenta-se uma discussão sobre os vários modos de enterramento no período cerâmico tardio do litoral central e do leste das Guianas ou sobre o 'horizonte de urnas', a fim de enfatizar a diversidade local' ${ }^{18}$. Assim sendo, a análise detalhada da cerâmica e dos modos de enterramento, sustentados por grandes escavações, revelou a existência de vários complexos locais, ao invés de uma única tradição cerâmica supraregional, que apresenta como modo dominante os enterramentos em urnas. Essa linha de pensamento é proeminente nas Antilhas, que atribui o desenvolvimento e a mudança cultural não só como resultado unilinear de eventos migratórios, mas relacionada a um mecanismo

15 BPS são os sítios da Barragem de Petit-Saut (Vacher et al., 1998).

16 "Les formes qui nous paraissent distinctives de la céramique de la culture Barbakoeba ne sont pas non plus systématiquement présentes (jatte ovale polylobée, plat creux à colombin apparent)".

17 Aqui utilizo a palavra "verniz", que é derivada do "verniz Saladoide", primeiro proposto por Keegan (2001, p. 238), porque este conceito também pode ser aplicado a Barbakoeba. De fato, ele se refere à aparente homogeneidade das cerâmicas Saladoides, conforme representado, em geral, por amplos modos de decoração regionais, tais como a pintura branca sobre vermelho e incisões zona hachurada, que tende a ser obscuro para determinar o grau de heterogeneidade da cultura material e o desenvolvimento cultural divergente em um nível local ou regional. Além disso, de modo similar, em minha opinião, a interpretação dos cacicados do período cerâmico tardio nas Guianas também obscurece a diversidade regional.

18 Embora o conceito de horizonte seja um tanto obsoleto na Arqueologia da América do Sul, ele é aqui utilizado conforme discutido por Willey e Philips (1958, p. 32), enquanto a noção de horizonte de urnas é suscetível de ser compreendida a partir da perspectiva das chamadas 'culturas de urnas', conforme encontrado na Europa Central durante a Idade do Bronze Tardia, por volta de 1000 A.C., quando por um breve período modos intermediários altamente similares foram usados em uma ampla área por diferentes populações.

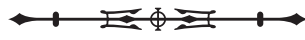


contínuo de difusão, troca e migração (Keegan, 2004; Hofman et al., 2007; Bright, 2011).

\section{CEMITÉRIOS TARDIOS (LCA)}

De fato, sítios exclusivamente cemitérios, contendo "urnas funerárias elaboradas", foram localizados somente no leste da Guiana Francesa, próximos à fronteira com o Brasil, conforme apontado por Rostain para a necrópole Aristé, nos sítios em cavernas Ouanary (Rostain, 1994, p. 103). O sítio AM 41 possui claramente uma área separada para os mortos, provavelmente no entorno de um sítio habitacional. Por outro lado, o sítio de Balaté apresenta a integração dos mortos ao sítio-habitação, o que parece ser um traço mais comum do que a deposição dos mortos em áreas separadas. Os enterramentos situados no sítio-habitação evocam a coexistência dos vivos e dos mortos, situação sempre registrada nos documentos históricos. Outra possibilidade é que o morto tenha sido enterrado em casas abandonadas, criando "a casa do morto" e, desse modo, sugerindo a existência de preocupação com a vida post-mortem, conforme evidenciado a partir dos enterramentos em forma de 'caixa' de AM 41 (van den Bel, 2009, p. 243, figura 9) ${ }^{19}$.

Em contraste com as urnas sóbrias do oeste da Guiana Francesa, as encontradas no Oiapoque e no Amapá quase sempre possuem formas complexas e são lindamente pintadas, o que as torna objetos apreciados por exploradores, pesquisadores, mas também pelo tráfico ilegal. $\bigcirc$ interesse por este tipo de cerâmica, apesar de estes sítios estarem situados em áreas remotas, provavelmente frustrou a descoberta de outros sítios funerários, a exemplo de necrópoles mais modestas como AM 41, embora este tipo de necrópole seja conhecido desde o início do século $X X$, como em Caviana (Curt Nimuendajú apud Stenborg, 2004, p. 67-90).

É importante destacar que os sítios funerários são mais facilmente identificados quando os ossos humanos (queimados e/ou não queimados) são encontrados, os quais são mais bem preservados quando ocorre a deposição em urnas colocadas em abrigos rochosos, do que os depositados em áreas a céu aberto, especialmente nos trópicos. Para encontrar um cemitério composto de urnas durante um levantamento ou em uma escavação, é necessário explorar ou escavar uma extensa superfície. Apenas escavações extensivas podem revelar a organização espacial de uma necrópole a céu aberto, como também os enterramentos simples em sítios-habitação. $\bigcirc$ último caso é quase sempre observado durante operações relacionadas à arqueologia preventiva, conforme se vê em grandes escavações, tais como em BPS 230 e BPS 172, Katoury, Eva 2, Crique Sparouine, La Pointe de Balaté, Chemin Saint-Louis, Wayabo, Sable Blanc Est, Cimetière paysager Poncel etc.

Finalmente, é raro encontrar uma necrópole, pois elas parecem estar confinadas a um espaço restrito e são quase sempre enterradas na floresta, conforme o caso da necrópole de AM 41 e Pointe Morne. Nas seções seguintes, será apresentada uma descrição de vários costumes funerários do período cerâmico tardio no segmento do litoral, de leste para oeste: (a) Oiapoque, (b) ilha Caiena, (c) Iracoubo, (d) Maroni/Mana e (e) Paramaribo.

\section{Oiapoque}

A primeira área, situada entre os rios Caiena e Araguari, é a melhor conhecida, pois é a região onde as urnas antropomorfas Aristé tardias podem ser encontradas. Estas urnas estão quase sempre em abrigos sob-rocha ou em pequenos poços, que são geograficamente separados da aldeia - sítios habitacionais Aristé não foram escavados na Guiana Francesa. Estes sítios são conhecidos desde as primeiras escavações de Emílio Goeldi no Amapá (Goeldi, 1900; Nimuendajú, 1926; Meggers e Evans, 1957; Hilbert, 1957; Cabral e Saldanha,

\footnotetext{
19 Os enterramentos 'em forma de caixas' são provavelmente inumações primárias ou secundárias em poços retangulares, com fragmentos
} de assadores na posição vertical, marcando a parede da tumba. 
2007, 2009, 2010)20. Na Guiana Francesa, urnas Aristé tardias são conhecidas desde os trabalhos de Hugues Petitjean Roget (1983, 1995b) e de Stéphen Rostain (1994) nos anos 1980, nos Montes de Ouanary e, mais recentemente, pelas escavações do INRAP relativas à ponte internacional no rio Oiapoque (Mestre e Hildebrand, 2011).

As cavernas e os poços funerários contêm quase sempre urnas antropomorfas lindamente trabalhadas com tempero de caco moído, bem como outros tipos de cerâmicas altamente decoradas, pratos quadrangulares com figuração de jaguar, assim como os chamados "raladores" cerâmicos (Hilbert, 1957, p. 15). O material osteológico sempre foi encontrado nessas urnas, sugerindo o uso desses apetrechos para enterramento secundário, nos quais ossos longos foram preservados. Os poços em forma de bota foram escavados no subsolo (algumas vezes atingindo cerca de dois metros de profundidade), nos quais foram colocadas as urnas. Esses poços foram provavelmente fechados com uma pedra para cobrir a entrada, conforme registrado no Amapá (Goeldi, 1900; Cabral e Saldanha, 2009). As complexas formas cerâmicas, com decorações elaboradas, sugerem representações de roupa, pintura corporal, joias, tatuagens etc., que possivelmente refletem o status social desses indivíduos, por exemplo como líderes, xamãs, ancestrais, linhagens, etc. (na aldeia e/ou na guerra), conforme tem sido pensado para outros sítios funerários no Amapá (Guapindaia, 2001) ou Marajó (Schaan, 2004), e que vêm sendo referidas como cerâmica cerimonial (Roosevelt, 1991, p. 370-371).

Como contas de vidro e outros artefatos importados foram encontrados nas urnas Aristé (mas também nas urnas Aruã e Maracá), a ideia de que esta tradição funerária continuou em épocas coloniais tem sido aceita (Goeldi, 1900; Meggers e Evans, 1957; Curt Nimuendajú apud Stenborg, 2004). Entretanto, também é possível que estas urnas pré-coloniais tenham sido reutilizadas pelas populações históricas como objetos ancestrais "sagrados", para servir novamente como artefatos funerários, conforme parece ter sido comum entre os Palikur (Curt Nimuendajú apud Stenborg,, 2004, p. 43-44)²1.

\section{Ilha de Caiena}

Os mortos de ilha de Caiena durante o período cerâmico tardio foram enterrados em poços retangulares profundos ou de formato alongado com paredes retas. Estes enterramentos foram reconhecidos em muitos sítios na ilha de Caiena, desde a introdução de escavações extensivas (Jérémie, 2002; Mestre, 2003). A hipótese é a de que, uma vez que o poço tenha sido cavado, o corpo foi depositado nele em uma posição estendida, sendo coberto com recipientes cerâmicos de uso doméstico, tanto quebrados como completos (Delpech, 2011, 2013). Outros objetos pessoais ou utensílios foram colocados no poço mortuário, mas não há evidência arqueológica de rituais funerários, a exemplo da cobertura com vasilhas cerâmicas e fragmentos nas fontes históricas.

Mais ainda, o sítio Poncel mostrou um alinhamento de três poços funerários, enquanto Saint-Cyr e Mombin II exibem concentrações de quatro a seis poços funerários (Delpech, 2013; van den Bel, 2014). Diferente dos sítios Aristé tardios, estes enterramentos estão situados próximo ao sítio habitacional ou dentro dele, e, em alguns casos, podem representar enterros separados. No momento, não há evidência de que estes enterramentos tenham sido marcados na paisagem. A deposição cerâmica em urnas

\footnotetext{
20 Mais ao sul, sítios com urnas funerárias atribuídos aos complexos cerâmicos Mazagão e Maracá também são parte desse 'horizonte cerâmico de urnas tardio', mas não foram incluídos na discussão, uma vez que esse tipo de urna não foi encontrado na Guiana Francesa nem no Suriname. Entretanto, escavações recentes no Larajal do Jari evidenciaram a convivência de urnas Mazagão, Caviana e Koriabo (Saldanha e Cabral, 2009, 2011).

${ }^{21}$ É notável que uma urna policrômica em forma de caixão com uma tampa plana, que parece ser uma imitação cerâmica de um caixão europeu (cristão), tenha sido encontrada na cavidade de Trou Delft, e localizada em Mont Caripo ou atualmente Mont Bruyère, ao leste da localidade moderna de Ounary (Petitjean Roget, 1995a, 1995b).
} 
também tem sido encontrada entre estes sepultamentos em posição estendida, bem como outros traços que se parecem com os encontrados em Iracoubo ${ }^{22}$.

\section{Iracoubo}

O sítio AM 41 claramente mostra um enterramento isolado. Ele consiste em duas concentrações de urnas com cerca de $20 \mathrm{~cm}$ de deposição em cada uma e que, provavelmente, foi marcado por um pequeno montículo funerário feito de areia, cobrindo parcialmente as urnas. Apenas em Caiena, os artefatos cerâmicos utilizados em contexto funerário consistem em objetos de uso doméstico, e não cerâmica altamente decorada, tais como as Aristé tardia, embora algumas destas vasilhas possam ter sido manufaturadas para essa ocasião. Existem dois tipos de poços: (a) um poço pequeno para abrigar artefatos cerâmicos e (b) um mais amplo, de formato retangular, que contém cerâmicas notadamente assadores ou grandes fragmentos de corpo de vasilhas (van den Bel, 2009).

Existe ainda uma diferenciação no modo de deposição de um único artefato ou de um grupo, quase sempre vasilhas temperadas com caco moído colocadas no poço: em pé, viradas ou colocadas uma sobre as outras. É provável que os poços retangulares possam indicar diferenças de status social, tendo em vista a raridade deste tipo de poço com concentração, a posição no centro ou a possível existência de bens funerários. Imagina-se que estes poços tenham sido reservados para líderes ou xamãs, sendo sua família (tanto parentes de sangue quanto mulheres ou escravos) colocada ao redor deles. Outros trabalhos de campo no nordeste da necrópole AM 41 revelaram a presença de muito mais urnas, que compartilham feições similares com as mencionadas, notadamente os fragmentos empilhados, urnas duplas e "caixas" (Briand, 2012). Estes enterramentos estão situados na margem arenosa - a mesma do sítio SBE - e mostram múltiplas concentrações ao longo de RN 1 por mais de $2 \mathrm{~km}$ de extensão, todas provavelmente coincidindo com feições habitacionais. Tendo por base fontes históricas e etnográficas, a hipótese é a de que estas concentrações de enterramentos estejam localizadas em aldeias abandonadas. As novas aldeias foram fundadas em locais mais acima na mesma margem, na qual as antigas aldeias foram usadas como cemitérios e locais de plantios. Foi deste modo que as aldeias diacrônicas emergiram nas margens arenosas da zona costeira da Guiana Francesa, durante o período cerâmico tardio ${ }^{23}$.

\section{Rios Mana/Maroni}

Entre a segunda metade dos anos 1980 e início dos anos 2000, apenas duas urnas foram reportadas pela população local Kali'na nas aldeias de Awala e Yalimapo/Les Hattes, sobre as quais existem documentos escritos (Cornette, 1987; Janin, 2002; Thomas, 2002). A primeira urna, encontrada em 1987, consiste em um enterramento secundário em urna globular que foi quebrada na base do gargalo. Ela foi coberta com uma grande tigela aberta ${ }^{24}$. Em 1997, a reconstrução da estrada ao longo da CD 7 próximo a Awala, na chamada Zona IV, conforme descrito por Alain Cornette (1987), também revelou uma urna globular que foi intencionalmente quebrada no colo e que apresentava quatro alças verticais aplicadas na parte mais alta da parede, acima da base do gargalo (Sylvie Jérémie, comunicação pessoal, 2010). Ambas as urnas contêm ossos humanos, os quais forneceram uma data de $865 \pm 40$ AP (PA-1945) (Thomas, 2002, p. 15; Janin, 2002, p. 41).

Ao lado dos ossos humanos, a urna de 1997 continha uma variedade de ossos de animais, tais como de cutia (Dasyprocta agouti), cutiara (Myoprocta acouchi), paca (Agouti paca), macaco capuchinho (Cebus sp.) e veado (Odocoileus sp.), conforme determidado por Sandrine

${ }^{22}$ Consultar também Mont Grand-Matoury para urnas funerárias possíveis (Grouard e Tardy, 2003, figuras 8 e 12).

${ }^{23}$ Outros prováveis sítios de urnas são esperados no baixo rio Organabo, bem como em Pointe Brigandin, na margem esquerda do rio Sinnamary (Petitjean Roget, 1995b). O último revelou uma possível urna, e o primeiro é conhecido apenas a partir de informações locais, o que também era o caso de Iracoubo antes das escavações de 2006.

${ }^{24}$ Os Kali'na de Awala consideram esta urna como uma vasilha de cashiri e a tampa como um artefato para conter água (Cornette, 1987). 
Grouard e Eric Pellé (2002). De acordo com esses autores, isso possivelmente poderia refletir certos privilégios tendo esses animais como oferendas. É provável que mais de uma urna tenha sido encontrada pela população local Kali'na, que tinha conhecimento de que este sítio pré-colonial costumava ser usado como cemitério (Cornette, 1987).

Mais recentemente, uma urna globular foi reportada em Alatou, em Awala, a qual também apresenta um reforço ao redor da base do gargalo, compartilhando um traço característico com Saint-Louis Fase 3 (van den Bel, 2012, p. 23, figura 7n versus Coutet, 2009, p. 343). Ela forneceu duas datas correspondendo à datação de Saint-Louis e Balaté, das quais Alatou e Alatou 2 (Coutet, 2011), correspondendo às series SBE (Tabela 6). Esta urna também poderia conter vasilhas menores, além de uma boa quantidade de contas de madrepérola (Coutet, 2011), as quais também foram notadas no sítio histórico Eva 2 (van den Bel et al., 2006, p. 116)25.

Não está claro se o morto foi colocado inteiro na urna globular. Entretanto, é mais provável, devido ao gargalo estreito, que uma seleção de ossos tenha sido feita para deposição na urna ou ao lado dela. Finalmente, pouco se sabe sobre a distribuição espacial destas urnas e como elas são organizadas, o que indica a necessidade da realização de novas pesquisas arqueológicas extensivas.

\section{Paramaribo}

A oeste de Paramaribo, várias urnas foram desenterradas no sítio monticular de Hertenrits. Diferentes modos de enterramento foram registrados: primário e secundário em urnas (Geijskes, 1963; Boomert, 1980). O sítio Peruvia 2, situado a oeste do rio Coppename, revelou duas urnas funerárias, das quais uma possuía uma tampa cerâmica e continha vestígios humanos (Versteeg, 1985, p. 722-723). Entretanto, a única necrópole próxima a Paramaribo é provavelmente o sítio Kwatta/Tingiholo. As escavações conduzidas por Geijskes nos anos 1950 revelaram 38 enterramentos primários, dos quais quatro crânios foram cobertos com uma vasilha cerâmica completa, que servia de tampa, sendo colocada na posição invertida, próximos a uma urna com enterramento secundário que provavelmente continha um corpo completo (Khudabux et al., 1991). No que tange aos numerosos crânios humanos, a deformação craniana voluntária foi identificada por pesquisas posteriores (Tacoma et al., 1991). Duas datações radiocarbônicas de ossos humanos situaram esse conjunto entre o século VII e XII AD (Versteeg, 2003, p. 159)²6.

\section{CONSIDERAÇÕES FINAIS}

Esta breve síntese dos diversos tipos de enterramentos encontrados nos sítios do período cerâmico tardio no Suriname, na Guiana Francesa e no norte do Amapá, revela importantes diferenças entre estes cemitérios, mas a expectativa é a de que todos eles sejam separados do sítio-habitação, formando verdadeiras necrópoles. Uma fronteira cultural é atravessada quando se comparam urnas funerárias de Iracoubo com as do norte do Amapá. A segunda área revela, na maior parte dos casos, cerâmica altamente decorada e antropomorfa, enquanto a primeira área contém formas abertas simples, quase sempre não decoradas. Entretanto, as deposições cerâmicas são organizadas em ambos os casos: as cerâmicas Aristé tardias são encontradas em concentrações nos poços profundos ou cavernas, enquanto as Iracoubo são agrupadas em concentrações circulares. Ambos os tipos de cemitérios são marcados por trabalhos de terra, diques ou estruturas

\footnotetext{
${ }^{25}$ Embora esteja além do escopo deste artigo, o sítio histórico Eva 2 tinha uma distribuição em pares; todas as inumações eram de indivíduos em posição fletida, com exceção de uma urna funerária, a qual estava associada a um enterramento estendido (van den Bel et al., 2006, 2015).

${ }^{26}$ Recentemente, toda a coleção "Geijskes" (contendo vestígios humanos de Kwatta/Tingiholo ( $\left.N=25\right)$, Hertenrits ( $\left.N=8\right)$, Okrodam $(N=3)$, Saramacca $(N=4)$, Waterkant $(N=2)$ e Aruba $(N=1)$, localizada na Universidade de Leiden, Holanda, foi revisada por Anne van Duijvenbode para analisar padrões de deformação craniana (van Duijvenbode, 2012).
} 
de pedra. Em ambos os casos, eles também refletem estratificação social e veneração de ancestrais.

As diferenças entre a ilha de Caiena, Iracoubo e o baixo rio Maroni são menos óbvias, mas uma distinção pode ser feita com relação às formas de inumação, aos poços alongados (Caiena) e aos enterramentos principalmente secundários em vasilhas domésticas (Iracoubo e Maroni). Deve-se notar, no entanto, que os sítios cerâmicos tardios de Caiena, tais como Poncel, também apresentam deposição em vasilhas (provavelmente mais tardio; van den Bel, 2014, p. 81-82), enquanto os poços em forma de 'caixa' de Iracoubo também podem conter inumações. Todavia, uma diferença importante entre Iracoubo e o baixo rio Maroni/Paramaribo é o tipo de vasilha: Iracoubo apresenta vasilhas abertas simples, enquanto o baixo Maroni/Paramaribo possui grandes urnas globulares com gargalos verticais ou extrovertidos, os quais são quase sempre decorados na base com apliques. Dito isso, não se deve esquecer que Balaté também apresenta inumações, bem como deposições cerâmicas, demonstrando que este esquema é altamente tentativo.

Concluímos que as populações do período cerâmico tardio fizeram uso de cemitérios separados na zona costeira atlântica das Guianas oriental, os quais foram usados para lembrar os mortos, provavelmente seus ancestrais, tais como caciques ou fundadores de aldeias, o que é sustentado pela variedade de tipos de enterramentos, sugerindo estratificação social. Entretanto, os sepultamentos nos sítios habitacionais necessitam de maior discussão; estes tipos de sítio são provavelmente multicomponenciais ou palimpsestos. Propomos aqui que: a) os cemitérios são apenas para certos membros da sociedade, conforme tem sido sugerido para outros cemitérios isolados no nordeste da Amazônia (Guapindaia, 2001); b) os sítios-habitação têm duas funções (habitação e funerária) simultaneamente; c) sítios habitacionais são aldeias que foram deslocadas, nas quais a parte antiga e abandonada da aldeia é usada como cemitério, sendo finalmente uma 'aldeia dos mortos'; d) os sítios-habitação servem parcialmente aos ritos funerários, nos quais a lamentação, a dança etc., é realizada na aldeia e o sepultamento de fato é feito fora dela, conforme sugerido pelo exemplo do Padre Eléazar Fauque (1835, p. 8):

J'entrai dans une [c]ase haute, que nous appelons soura en langage galibi; m'entretenant avec ceux qui l'habitoient, je fus tout à coup saisi $d$ une odeur cadavereuse; et commej'en témoignai ma surprise, on me dit qu'on venoit de déterrer les ossemens d'un mort, qu'on devoit transporter dans une autre contrée, et l'on me montra en même temps une espèce d'urne qui renfermoit ce dépôt. Je me ressouvins alors que j'avois vu ici, il y a trois ou quatre ans, deux Palikours, lesquels étoient venus chercher les os d'un de leurs parens qui y étoit mort. Comme je ne pensois pas alors à les questionner sur cette pratique, je le fis en cette occasion, et ces sauvages me répondirent que l'usage de leur nation étoit de transporter les ossemens des morts dans le lieu de leur naissance, qu'ils regardent comme leur unique et véritable patrie.

A lembrança e a conservação dos restos dos membros do grupo ou da família são direcionadas para o lugar do cemitério ou da aldeia, que representam elementos culturais importantes da organização social, cerimonial e política das populações tardias. Os cemitérios separados e/ou habitações antigas marcam também lugares de culto e do território do grupo, materializados na paisagem por meio de cabeções, pedras elevadas, diques etc. (Betendorf, 1910, p. 353-354).

Finalmente, temos uma região costeira com um padrão de urnas compartilhadas ou um horizonte funerário no período cerâmico tardio, na costa das Guianas oriental. Entretanto, outras análises dos modos de enterramentos mostram que diferenças locais podem ser detectadas, revelando particularidades ou regionalidades. Este padrão é sustentado por análises cerâmicas detalhadas (ambas tecnológicas e morfológicas), revelando conjuntos específicos por região, os quais nem sempre se restringem às principais características dos complexos cerâmicos do período tardio, tais como Barbakoeba. As formas apresentadas podem certamente ser atribuídas a este complexo, que se distribui por cerca de 500 km ao longo do litoral da Guiana, entre Caiena e Paramaribo, expandindo, desse modo, o registro cerâmico e dando um primeiro passo em direção às diferenças regionais. 


\section{AGRADECIMENTOS}

O autor gostaria de agradecer a Jérôme Briand, pela análise da cerâmica de Balaté; a Arie Boomerte aos dois pareceristas, pelos comentários; bem como a Denise Maria Cavalcante Gomes, pela tradução, e também aos Editores do Boletim do Museu Paraense Emílio Goeldi. Ciências Humanas.

\section{REFERÊNCIAS}

BALFET, Hélène; FAUVET-BERTHELOT, Marie-France; MONZON, Suzanne. Lexique et typologie des poteries: pour la normalisation de la description des poteries. Paris: Presse du CNRS, 1989.

BARONE-VISIGALLI, Egle; PROST, Marie-Thérèse. Modalités d'occupation des sites amérindiens en Guyane: le cas de la Sablière, à Kourou. Cayenne: Direction des Antiquités, 1991.

BETENDORF, João Felipe. Chronica da Missão dos Padres da Companhia de Jesus no Estado do Maranhão. Revista do Instituto Historico e Geographico Brasileiro, tomo LXXII, parte I, p. 1-697, 1910.

BOOMERT, Arie. Koriabo and the Polychrome Tradition: the Late-Prehistoric Era between the Orinoco and Amazon mouths. In: DELPUECH, André; HOFMAN, Corinne (Eds.). Late Ceramic Age Societies in the Eastern Caribbean. London: Archaeopress, 2004. (BAR International Series, 1273; Paris Monographs in American Archaeology, 14). p. 251-266.

BOOMERT, Arie. The Barbakoeba archaeological complex of northeast Suriname. OSO: Tijdschrift voor Surinamistiek, v. 12, n. 2, p. 98-222, 1993.

BOOMERT, Arie. The Cayo Complex of Saint-Vincent: ethnohistorical and archaeological aspects of the Island Carib problem. Antropológica, v. 66, p. 3-68, 1986.

BOOMERT, Arie. Hertenrits: an Arauquinoid Complex in North West Suriname. Journal of the Walter Roth Museum of Archaeology and Anthropology, v. 3, n. 2, p. 68-104, 1980.

BOOMERT, Arie. Report on ceramic samples from Itabru, Berbice River. Journal of the Walter Roth Museum of Archaeology and Anthropology, v. 2, n. 1, p. 79-86, 1978.

BOOMERT, Arie. Prehistorie. In: BRUIJNING, Conrad; VOORHOEVE, Jan (Eds.). Encyclopedie van Suriname. Amsterdam: Elsevier, 1977. p. 506-517.

BRIAND, Jérôme. Les fouilles préventives de la Pointe Balaté (Saint-Laurent-du-Maroni). Rapport de Fouille INRAP. Cayenne: INRAP, 2015.

BRIAND, Jérôme Redressement RN 1, Phase III, Iracoubo Guyane. Rapport de Dianostic. Cayenne: INRAP, 2012.
BRIAND, Jérôme. Wayabo. Kourou, Guyane. Rapport de Diagnostic. Cayenne: INRAP, 2011.

BRIGHT, Alistair. Blood is thicker than water: amerindian occupation and the intra- and inter-insular relationships in the Windward Islands. 2011. Tese (Doutorado em Arqueologia) - University of Leiden, Leiden, 2011.

CABRAL, Mariana Petry. Juntando cacos: uma reflexão sobre a classificação da Fase Koriabo no Amapá. Amazônica, v. 3, n. 1, p. 88-106, 2011.

CABRAL, Mariana Petry; SALDANHA, João Darcy. Ocupações pré-coloniais no setor Costeiro Atlântico do Amapá. In: PEREIRA, Edithe; GUAPINDAIA, Vera (Orgs.). Arqueologia amazônica. Belém: MPEG/IPHAN/SECULT, 2010. v. 1, p. 49-60.

CABRAL, Mariana Petry; SALDANHA, João Darcy. Note sur des structures mégalithiques en Guyane brésilienne, Amapá. Journal de la Société des Américanistes, v. 95, n. 1, p. 97-110, 2009.

CABRAL, Mariana Petry; SALDANHA, João Darcy. Projeto de investigação arqueológica na Bacia do Rio Calçoene e seu entorno, AP: Relatório Final para IPHAN. Macapá: Instituto de Pesquisas Cientificas e Tecnológicas do Estado do Amapá, 2007.

CORNETTE, Alain. La céramique amérindienne de Guyane. In: CONGRESS OF THE INTERNATIONAL ASSOCIATION FOR CARIBBEAN ARCHAEOLOGY AT PUERTO RICO, 11., 1985, San Juan. Proceedings... San Juan: The Foundation of Archaeology, Anthropology and History of Puerto Rico, 1990. p. 196-213.

CORNETTE, Alain. Quelques données sur l'occupation amérindienne dans la région basse Mana, bas Maroni, d'après les sources ethnoarchéologiques. Equinoxe, Revue de Sciences Humaines, v. 24, p. 70-99, 1987.

COUTET, Claude. La caractérisation techno-stylistique de la céramique de la Tradition arauquinoïde en Guyane: une approche ethnoarchéologique de la céramique amérindienne. Karapa, v. 3, p. 6-20, 2014a.

COUTET, Claude. Un an de prospection à Awala-Yalimapo, Guyane: le site funéraire de yalimapo. In: BERARD, Benoît; LOSIER, Catherine (Eds.). Archéologie caraïbe. Leiden: Sidestone Press, Leiden, $2014 \mathrm{~b}$. (Collection Tabouï 2). p. 201-222.

COUTET, Claude. Prospections Awala-Yalimapo. Rapport DRAC/ SRA. Cayenne: DRAC, 2011.

COUTET, Claude. Archéologie du Littoral de Guyane française: une approche ethnoarchéologique des techniques céramiques amérindiennes. 2009. Tese (Doutorado em Arqueologia) Université de Paris I Panthéon-Sorbonne, Paris, 2009.

COUTET, Claude; ROMON, Thomas; SERRAND, Nathalie. Ossements et perles en coquillage des sépultures précolombiennes de Yalimapo (Awala-Yalimapo). Karapa, v. 3, p. 21-34, 2014. 
DELPECH, Sandrine. La fouille de Mombin II: un nouveau mode d'inhumation dans la Guyane Française. In: INTERNATIONAL CONGRESS OF CARIBBEAN ARCHAEOLOGY, 25., San Juan, 2013. Proceedings... San Juan: IACA, 2013.

DELPECH, Sandrine. Mombin, Rémire-Montjoly, Guyane. Rapport Final d'Opération Diagnostic Archéologique. Cayenne: INRAP, 2011.

EVANS, Clifford; MEGGERS, Betty. Archaeological investigations in British Guiana. Washington: Smithsonian Institution, 1960. (Bulletin Bureau of American Ethnology, 177).

FAUQUE, Eléazar. Lettre du Père Fauque, missionnaire de la Compagnie de Jésus, au Père de la Neuville, A Ouyapoc, le 20 septembre 1736. In: MONTMIGNON, Jean Baptiste. Choix des Lettres Edifiantes, écrites des missions étrangères. Paris: Imprimerie Casimir, 1835. (Missions de l'Amérique, v. 7). p. 1-13.

GASSIES, Eric; DAUPHIN, Guy. Angoulême, Mana, Bilan scientifique Guyane. Cayenne: Direction Regionale des Affaires Culturelles, 2013.

GEIJSKES, Dirk Cornelis. Les Arawaks dans la Préhistoire de Surinam. In: BULLEN, Ripley (Ed.). Full texts of all communications and debates of the First International Convention for the Study of preColumbian culture in the Lesser Antilles, Fort-de-France 1961. Fort-de-France: Société d'Histoire de la Martinique, 1963. p. 71-78.

GOELDI, Emílio. Excavações archeologicas en 1895. Executadas pelo Museu Paranese no Littoral da Guyana Brazileira entre Oyapock e Amazonas. Primera Parte. As cavernas funerárias artificiaes de Índios hoje extinctos no Rio Cunany (Goanany) e sua cerâmica. Belém: Museu Paraense de História Natural e Ethnographia, 1900. 49 p. il. (Memórias do Museu Goeldi, I).

GROENE, Denis. Note sur le site de Kormontibo. In: INTERNATIONAL CONGRESS FOR THE STUDY OF PRECOLOMBIAN CULTURES OF THE LESSER ANTILLES, POINTEA-PITRE, 6., 1975, Guadeloupe. Proceedings... Guadeloupe: Société d'Histoire de la Guadeloupe et la Municipalité de Pointe-àPitre, 1976. p. 158-164.

GROUARD, Sandrine; TARDY, Christophe. Un site d'habitat de hauteur sur le mont Grand Matoury, Île de Cayenne-Guyane française. In: DELPUECH, André; GIRAUD, Jean-Pierre; HESSE, Albert (Eds.). Archéologie précolombienne et coloniale des Caraïbes: Actes 123e Congrès National des Sociétés Historiques et Scientifiques, Antilles-Guyane 1998. Paris: Éditions du CTHS, 2003. p. 197-223.

GROUARD, Sandrine; PELLÉ, Eric. Rapport préliminaire: Les Vertébrés associés à une sépulture humaine - Awala-Yalimapo Guyane Française site no 97361004 P. Cayenne: DRAC, 2002.

GUAPINDAIA, Vera Lúcia Calandrini. Encountering the ancestors: the maracá urns. In: MCEWAN, Colin; BARRETO, Christina; NEVES, Eduardo Góes (Eds.). Unknown Amazon: culture and nature in ancient Brazil. London: British Museum Press, 2001. p. 156-173.
HILBERT, Klaus. Pottery from the Cuminá River, Brazil and its affiliations with the Koriabo Phase of Guyana. Journal of the Walter Roth Museum Archaeology and Anthropology, v. 5, n. 2, p. 74-81, 1982.

HILBERT, Peter Paul. Contribuição à arqueologia do Amapá. Fase Aristé. Boletim do Museu Paraense Emílio Goeldi, Nova Série, Antropologia, n. 1, p. 1-37, 1957.

HILDEBRAND, Matthieu. Saut-Saillat: une occupation diachronique de Berge Haute, Saint-Laurent du Maroni (Guyane Française). Rapport de Fouille. Cayenne: INRAP, 2008.

HILDEBRAND, Matthieu. Commune de Mana, prospectioninventaire et carte archéologique de la commune de Mana. DFS DRAC Guyane/SRA. Cayenne: DRAC, 2002.

HOFMAN, Corinne; BRIGHT, Alistair; BOOMERT, Arie; KNIPPENBERG, Sebastian. Island rhythms: the web of social relationships and interaction networks in the lesser Antillean archipelago between 400 BC and AD 1492. Latin American Antiquity, v. 18, n. 3, p. 243-268, 2007.

JANIN, Thierry. Awala-Yalimapo. Etude anthropologique de l'urne funéraire. Cayenne: DRAC, Service Régional de l'Archéologie, 2002. (Bilan Scientifique de la Guyane, 1999).

JÉRÉMIE, Sylvie. Commune de Rémire-Montjoly (97309). RN3 Poncel, nº opération 4023020201, Site 97309.104. Rapport de Diagnostic INRAP. Cayenne: INRAP, 2002.

KAYAMARÉ, Sandra. Opération "Basse Mana-Carte communale" Commune de Mana, Guyane 973. Document Final AFAN. Cayenne: AFAN, 1997.

KEEGAN, William. Islands of Chaos. In: DELPUECH, A.; HOFMAN, C. (Eds.). Late Ceramic Age Societies in the Eastern Caribbean. Oxford: Archaeopress, 2004. (BAR International Series, 1273; Paris Monographs in American Archaeology, 14). p. 33-44.

KEEGAN, William. Archaeological investigations on lle à Rat: avoid the -oid. In: INTERNATIONAL CONGRESS FOR CARIBBEAN ARCHAEOLOGY, 18., 1999, Grenada. Proceedings... Guadeloupe: Association Internationale d'Archéologie de la Caraïbe Région, 2001. p. 233-239.

KHUDABUX, Mugheri; MAAT, Georges; VERSTEEG, Aad. The remains of prehistoric Amerindians of the "Tingi Holo Ridge" in Suriname. A physical anthropological investigation of the "Versteeg Collection". In: INTERNATIONAL CONGRESS OF CARIBBEAN ARCHAEOLOGY CAYENNE, 12., 1987, Martinique. Proceedings... Martinique: Association Internationale d'Archéologie de la Caraïbe, 1991. p. 135-151.

MCKEY, Doyle; ROSTAIN, Stéphen, IRIARTE, José; GLASER, Bruno; BIRK, Jago; HOLST, Irene; RENARD, Delphine. Pre-Columbian agricultural landscapes, ecosystem engineers, and self-organized patchiness in Amazonia. Proceedings of the National Academy of Sciences, v. 107, n. 17, p. 7823-7828, 2010. 
MEGGERS, Betty; EVANS, Clifford. Archaeological investigations at the mouth of the Amazon. Washington: Smithsonian Institution, 1957. (Bulletin of the Bureau of American Ethnology, 167).

MESTRE, Mickaël. Saint-Georges de l'Oyapock. Piste provisoire du pont de l'Oyapock (Guyane-Française). Rapport de Diagnostic INRAP. Cayenne: INRAP, 2006.

MESTRE, Mickaël. Quelques données préliminaires sur le site de Katoury (Commune de Cayenne, Guyane). Journal de la Société des Américanistes, v. 89, n. 1, p. 177-185, 2003.

MESTRE, Mickaël; HILDEBRAND, Matthieu. Pointe Morne: la rencontre de deux mondes amérindiens. In: MIGEON, Gérald (Ed.). Un pont sur l'Oyapock: guide de l'exposition. Cayenne: MEEDT/ DRAC/DEAL, 2011. p. 10-13.

MIGEON, Gérald; COUTET, Claude; DAVY, Damien; GRENAND, Pierre; HANRIOT, Damien. Amérindiens de Guyane. Entre les fleuves Approuague et Oyapock, des cultures millénaires. Régina: MAN/EMAK/DRAC, 2010.

NIMUENDAJú, Curt. Die Palikur-Indianer und ihre Nachbarn. Göteborgs Kungl. Vetenskaps- och Vitterhets-Samhälles Handlingar, v. 31, n. 2, p. 1-144, 1926.

OSGOOD, Cornelius. British Guiana Archeology to 1945. New Haven: Yale University Press, 1946. (Yale University Publications in Anthropology, 36).

PETITJEAN ROGET, Hugues. Prospection archéologique de la zone côtière. Sondages sur le site de la Pointe Brigandin, Commune de Sinnamary, Guyane. Cayenne: DRAC, 1995a.

PETITJEAN ROGET, Hugues. Fouille de sauvetage urgent, Site $n^{\circ}$ 97112314.16, Trou Delft: un site funéraire post-colombien sur l'Oyapock en Guyane Française. In: CONGRESS OF THE INTERNATIONAL ASSOCIATION OF CARIBBEAN ARCHAEOLOGY, 15., 1993, San Juan. Proceedings... San Juan: Centro de Estudios Avanzados de Puerto Rico y el Caribe, 1995b. p. 377-392.

PETITJEAN ROGET, Hugues. Evolution et décadence de l'art funéraire des sites pré et post-colombiens de la baïe de l'Oyapock. In: ANNUAL INTERNATIONAL ASSOCIATION OF CRIME ANALYSTS, 9., 1983, Santo Domingo. Anais... Santo Domingo: IACA, 1983. p. 183-200.

RICE, Prudence. Pottery analysis: a sourcebook. Washington: University of Chicago Press, 1987.

ROOSEVELT, Anna Curtenius. Moundbuilders of the Amazon: geophysical archaeology on Marajó Island, Brazil. San Diego: Academic Press, 1991. (Studies in Archaeology).

ROSTAIN, Stéphen. Islands in the rainforest: landscape management in pré-Columbian Amazonia. Traduzido por Michelle Eliott. Walnut Creek: Left Coast Press, 2013. (New Frontiers in Historical Ecology, 4).
ROSTAIN, Stéphen. Between Orinoco and Amazon: the Ceramic Age in the Guianas. In: WHITEHEAD, Neil; ALEMAN, Stephanie (Eds.). Anthropologies of Guayana: cultural spaces in Northeastern Amazonia. Tucson: Arizona University Press, 2009. p. 36-54.

ROSTAIN, Stéphen. The archaeology of the Guianas: an overview. In: SILVERMAN, Helaine; ISBELL, William (Eds.). Handbook of South American Archaeology. New York: Springer, 2008. p. 279-302.

ROSTAIN, Stéphen. L'occupation amérindienne ancienne du littoral de Guyane. 1994. Tese (Doutorado em Arqueologia) Université Paris I-Panthéon-Sorbonne, Paris, 1994. 2 v.

ROSTAIN, Stéphen. Le site archéologique de Thémire: sauvetage urgent. Rapport intermédiaire. Cayenne: ORSTOM, 1989.

ROSTAIN, Stéphen; DÉODAT, Laure; CLERC, Lydie; GENTIL, Nicolas. Bois Diable. Rapport de Campagne 2009. Nanterre: CNRS/Université de Panthéon-Sorbonne, 2010.

ROSTAIN, Stéphen; DÉODAT, Laure; CLERC, Lydie. Bois Diable. Rapport de Campagne de la Fouille Programmée 2008. Nanterre: CNRS/Université de Panthéon-Sorbonne, 2009.

ROSTAIN, Stéphen; GUILLAUME-GENTIL, Nicolas; CLERC, Lydie. Sable Blanc Est. Rapport de la fouille programmée. Nanterre: CNRS/Université de Panthéon-Sorbonne, 2008.

ROSTAIN, Stéphen; VERSTEEG, Aad. The Arauquinoid tradition in the Guianas. In: DELPECH, André; HOFMAN, Corinne (Eds.). Late Ceramic Age Societies in the Eastern Caribbean. London: Archaeopress, 2004. (BAR International Series ,1273; Paris Monographs in American Archaeology, 14), p. 223-250.

ROSTAIN, Stéphen; VERSTEEG, Aad. Recherche sur l'archéologie de la côte occidentale de Guyane. Journal de la Société des Américanistes, t. 89, n. 1, p. 161-175, 2003.

ROUSE, Irving Benjamin. The classification of artifacts in archaeology. American Antiquity, v. 25, n. 3, p. 313-323, 1960.

ROUSE, Irving Benjamin. Prehistory in Haiti: a study in method. New Haven: Yale University Press, 1939. (Yale University Publications in Anthropology, 21).

RYE, Owen. Pottery technology: principles and reconstruction. Washington: Taraxacum, 1981.

SALDANHA, João Darcy; CABRAL, Mariana Petry. Primeiro relatório de resgate do sítio arqueológico Laranjal do Jari II. Documento do IEPA/IPHAN. Macapá: Secretaria de Transportes do Amapá, 2011.

SALDANHA, João Darcy; CABRAL, Mariana Petry. Relatório preliminar de resgate do sítio arqueológico Laranjal do Jari I. Documento do IEPA/IPHAN. Macapá: Secretaria de Transportes do Amapá, 2009. 
SAMUELIAN, Clara. Lieu dite Sainte Agathe, Macouria (Guyane 973). Rapport de Diagnostic. Cayenne: INRAP, 2009.

SCHAAN, Denise Pahl. The Camutins chiefdom: rise and development of social complexity on Marajó Island, Brazilian Amazon. 2004. Tese (Doutorado em Antropologia Social) University of Pittsburgh, Pittsburgh, 2004.

STENBORG, Per (Ed.). In Pursuit of a Past Amazon. Archaeological researches in the Brazilian Guyana and in the Amazon region. Göteborg: Museum of World Culture, 2004. (Ethnological Studies, 45).

TACOMA, Jouke; GEIJSKES, Dirk Cornelis; MAAT, Georges; VAN VARK, Gerrit. On "Amazondi”. Precolumbian skeletal remains and associated Archaeology from Suriname. Amsterdam: Foundation for Scientific Research in the Caribbean Region, 1991. (Publication of the Foundation for Scientific Research in the Caribbean Region, 127).

THOMAS, José. Awala-Yalimapo. Village et abords. Bilan Scientifique de la Région Guyane 1998. Cayenne: Service Régional de l'Archéologie, 2002. p. 15.

THOORIS, Catherine. Kourou, La Sablière du Bois Diable, Site amérindien de plein air. Cayenne: Service Régional de l'Archéologie de Guyane, 1994.

VACHER, Stephane; JEREMIE, Sylvie; BRIAND, Jérôme. Amérindiens du Sinnamary (Guyane): archéologie en forêt équatoriale. Paris: Éditions de la Maison des Sciences de l'Homme, 1998. (Document d'Archéologie Française, 70).

VAN DEN BEL, Martijn. Excavations at Poncel: an update of the Late Ceramic Age of Cayenne. In: ROSTAIN, Stéphen (Ed.). Antes de Orellana: Actas del 3er Encuentro Internacional de Arquéologia Amazônia. Quito: IFEA, 2014. (Actes \& Mémoires de l'Institut Français d'Etudes Andines, 37). p. 75-88.

VAN DEN BEL, Martijn. Archaeological investigations at the Saint-Louis on the Lower Maroni River: the Early Ceramic Series. Journal of the Walter Roth Museum of Archaeology and Anthropology, $v$. 17, n. 2, p. 1-52, 2012.

VAN DEN BEL, Martijn. A Koriabo site on the Lower Maroni river: results of the preventive archaeological excavation at Crique Sparouine, French-Guiana. In: PEREIRA, Edithe; GUAPINDAIA, Vera (Orgs.). Arqueologia amazônica. Belém: MPEG/IPHAN/SECULT, 2010. v. 1, p. 61-93.

VAN DEN BEL, Martijn. Les dépôts funéraires d'Iracoubo: les résultats d'une fouille préventive d'une nécropole précolombienne de Guyane Française. Amazônica, v. 1, n. 1, p. 230-249, 2009.
VAN DEN BEL, Martijn. Chemin-Saint Louis, Commune de SaintLaurent-du-Maroni. Rapport de Diagnostic. Cayenne: INRAP, 2008a.

VAN DEN BEL, Martijn. Balaté, Commune de Saint-Laurent-duMaroni. Rapport de Diagnostic. Cayenne: INRAP, $2008 \mathrm{~b}$.

VAN DEN BEL, Martijn. Parcelle Am 43 à Iracoubo, Sable Blanc Est, Commune d'Iracoubo. Rapport de Diagnostic. Cayenne: INRAP, 2006.

VAN DEN BEL, Martijn. Sinnamary. Carrières Soyouz Natacha, Olga, Tania et Irina (Guyane Française). Rapport de Diagnostic. Cayenne: INRAP, 2004

VAN DEN BEL, Martijn; ROMON, Thomas; VALLET, Christian; DELPECH, Sandrine. Un village "galibi" en Guyane française; le cas du site archéologique d'Eva 2. Recherches Amérindiennes au Québec, v. 44, n. 2, 2015. No prelo.

VAN DEN BEL, Martijn; HILDEBRAND, Matthieu; DELPECH, Sandrine; ROMON, Thomas; VALLET, Christian. Les occupations amérindiennes du site Eva 2, Chantier Soyouz du CSG, Malmanoury. Commune de Sinnamary, Guyane Française. Rapport de Fouille. Cayenne: INRAP, 2006.

VAN DUIJVENBODE, Anne. A reappraisal of intentional cranial modification among the indigenous inhabitants of Suriname in Prehistoric and Historic times. Caribbean Connections, v. 2, n. 1, p. 1-11, 2012.

VERSTEEG, Aad. Surinam before Columbus. Paramaribo: Stichting Surinaams Museum, 2003. (Libri Musei Surinamensis, 1).

VERSTEEG, Aad. The Prehistory of the young coastal plain of West Suriname. Berichten van de Rijksdienst voor het Oudheidkundig Bodemonderzoek, v. 35, p. 653-750, 1985.

VERSTEEG, Aad. $C^{14}$ dateringen van archeologische vindplaatsen in Suriname. Mededelingen Stichting Surinaams Museum, v. 32 , p. 38-56, 1980.

VERSTEEG, Aad; BUBBERMAN, Frans. Suriname before Columbus. Paramaribo: Mededelingen van de Stichting Surinaams Museum, 1992. v. 49, p. 3-65.

WACK, Yves. Petit atlas des formes et décors céramiques du gisement amérindien de Tonate-Sainte-Agathe. Cayenne, 1990.

WILLEY, Gordon; PHILIPS, Philip. Method and theory in American Archaeology. Chicago: University of Chicago Press, 1958.

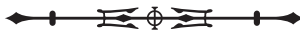

